\title{
Permian felsic volcanic rocks in the Pannonian Basin (Hungary): new petrographic, geochemical, and geochronological results
}

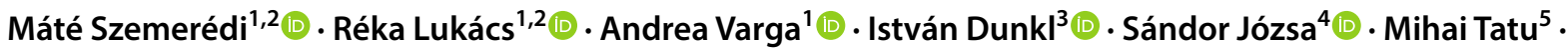

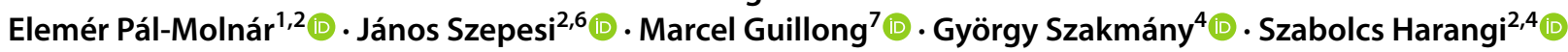

Received: 17 October 2018 / Accepted: 26 October 2019 / Published online: 18 November 2019

(c) The Author(s) 2019

\begin{abstract}
Two distinct Permian volcanic epochs were revealed in the Pannonian Basin (eastern Central Europe) by U-Pb zircon geochronology: an older one ( 281 Ma, Cisuralian) in the ALCAPA Mega-unit (Central Transdanubia, Hungary) and a younger volcanic episode ( 267-260 Ma, Guadalupian) in the Tisza Mega-unit (Southern Transdanubia and the eastern Pannonian Basin, Hungary). The former is represented by dacitic subvolcanic rocks (dykes) and lavas, while the latter is dominantly by crystal-rich rhyolitic-rhyodacitic/dacitic ignimbrites and subordinate rhyodacitic/dacitic lavas. Whole-rock (major and trace element) geochemical data and zircon U-Pb ages suggest close relationship between the samples of Central Transdanubia and volcanic rocks of the Northern Veporic Unit (Western Carpathians, Slovakia), both being part of the ALCAPA Mega-unit. Such correlation was also revealed between the Permian felsic volcanic rocks of the Apuseni Mts (Romania) and the observed samples of Southern Transdanubia and the eastern Pannonian Basin that are parts of the Tisza Mega-unit. The older volcanic rocks ( 281-265 Ma) could be linked to post-orogenic tectonic movements, however, the youngest samples ( $260 \mathrm{Ma}$, eastern Pannonian Basin, Tisza Mega-unit) could be formed in the extensional setting succeeding the post-collisional environment. On the whole, the observed Permian magmatic rocks show significant similarity with those of the Western Carpathians.
\end{abstract}

Keywords Permian $\cdot$ Felsic volcanism $\cdot$ Geochemistry $\cdot \mathrm{U}-\mathrm{Pb}$

\section{Introduction}

During the Permo-Carboniferous times several intramontane basins were formed along the European Variscan Orogenic Belt genetically controlled by a post-collisional to extensional tectonic regime associated with intense magmatic activity often having bimodal (basaltic-dacitic/rhyolitic) character (Cortesogno et al. 1998; Awdankiewicz 1999; Wilson et al. 2004; Paulick and Breitkreuz 2005; Vozárová et al. 2009, 2015, 2016; Seghedi 2010; Wilcock et al. 2013;

Máté Szemerédi, Réka Lukács and Andrea Varga have contributed equally to this work.

Electronic supplementary material The online version of this article (https://doi.org/10.1007/s00531-019-01791-x) contains supplementary material, which is available to authorized users.

Máté Szemerédi

h462582@stud.u-szeged.hu; szemeredi.mate@gmail.com

Extended author information available on the last page of the article
Letsch et al. 2014; Nicolae et al. 2014; Repstock et al. 2017; Ondrejka et al. 2018). The most primitive products of the Permo-Carboniferous magmatism are mantle-derived mafic lavas dominantly present in Northern Europe; however, shallow-level processes in the crust (e.g., magmatic differentiation, anatexis, and assimilation-fractional crystallization processes) resulted in more evolved felsic plutonic and volcanic rocks that are widespread in Europe (Wilson et al. 2004). The Upper Palaeozoic volcanic rocks are dominantly altered (K-metasomatized, hydrothermally altered, and low-grade metamorphosed) and show significant variety in both petrographic features and geochemical characteristics. Regarding felsic volcanism, the zircon $\mathrm{U}-\mathrm{Pb}$ ages vary from $\sim 300 \mathrm{Ma}$ (Latest Carboniferous) to $\sim 245-240 \mathrm{Ma}$ (Latest Permian-Earliest Triassic), suggesting a long-lasting magmatic activity during the Permo-Carboniferous (Awdankiewicz 1999; Wilson et al. 2004; Paulick and Breitkreuz 2005; Vozárová et al. 2009, 2015, 2016; Słodczyk et al. 2018; Ondrejka et al. 2018). 

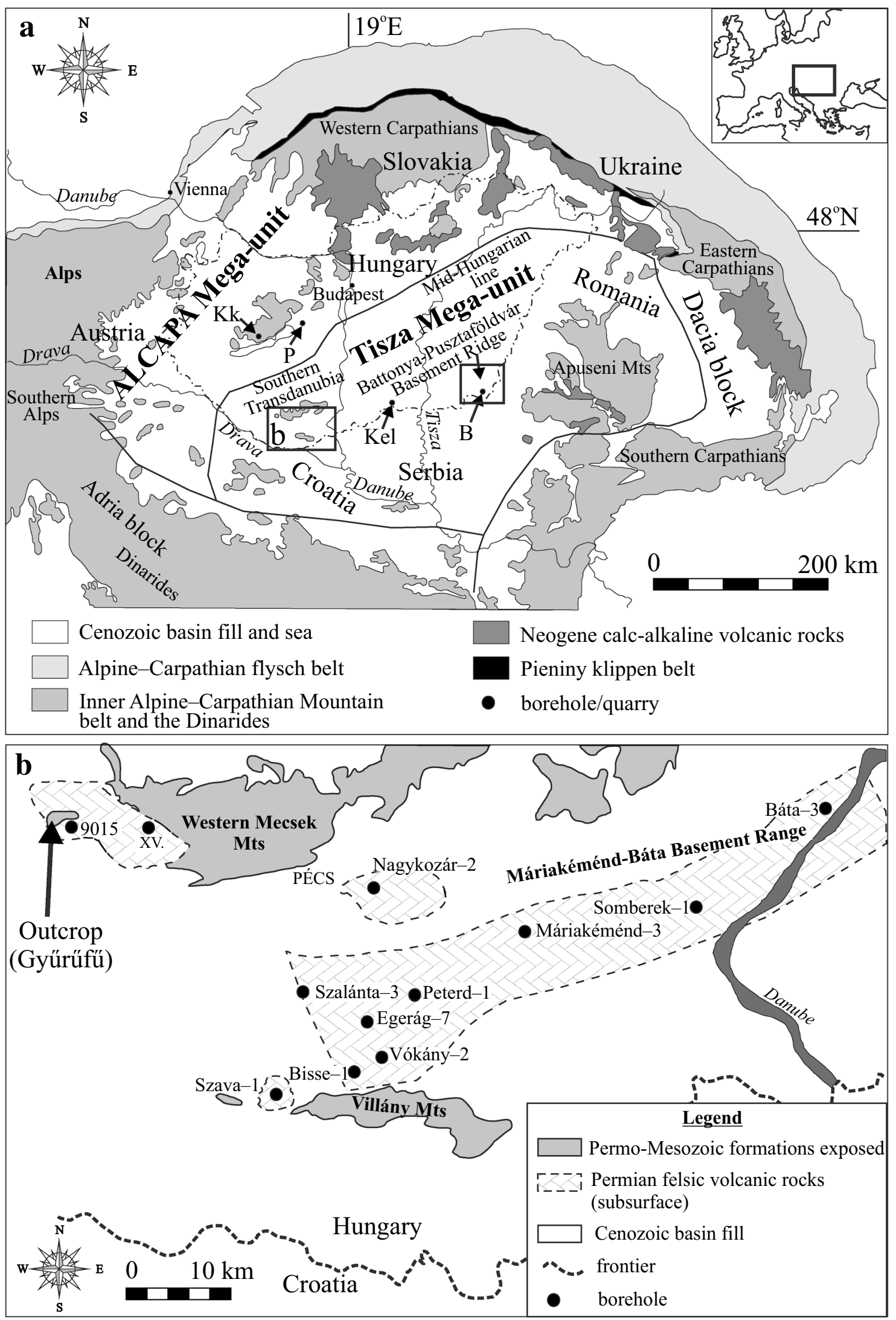
४Fig. 1 a Tectonic sketch of the Carpathian-Pannonian region indicating the subsurface contour of the mega-units. b Position of the studied Permian felsic volcanic rock outcrop and the boreholes of Southern Transdanubia, Hungary. Map base is modified after Szemerédi et al. (2017). B Battonya, Kel Kelebia, Kk Kékkút, $P$ Polgárdi

Permian volcanic activity was recognized in several parts of the Carpathian-Pannonian region (e.g., Lelkes-Felvári and Klötzli 2004; Haas et al. 2008; Vozárová et al. 2009, 2015, 2016, Ondrejka et al. 2018). During the formation of the Pannonian Basin in the Early Miocene, two terranes got into juxtaposition creating the basement of the basin (Haas et al. 1999). Both the European-derived Tisia Terrane (Tisza Mega-unit) and the ALCAPA Terrane (ALCAPA Megaunit, showing southern-Alpine affinity) bear the signs of the Permo-Carboniferous magmatism; however, there is limited petrographic, geochemical, or geochronological information about it. Permian rhyolitic ignimbrites and mafic-intermediate (basalt and subordinate andesite) lavas are exposed in the central-western part of the Apuseni Mountains, Romania (Nicolae et al. 2014; Fig. 1a), within the largest outcrop of the Tisza Mega-unit (Tisza MU) and also in the Hronicum (Central Western Carpathians, Vozár 1997; Dostal et al. 2003). In the western part of the Tisia Terrane, the only outcrop of these formations is known in the western part of the Mecsek Mts (Gyúrüfú and Dinnyeberki area, Fig. 1b; Szederkényi 1962; Barabásné Stuhl 1988; Hidasi et al. 2015; Szemerédi et al. 2016), but several deep boreholes, associated with the previous uranium ore exploration work, pierced such lithologies (Fig. 1b). Permian felsic volcanic rocks are also known in the ALCAPA Mega-unit (NorthWest Hungary), dominantly by boreholes (e.g., well Kékkút-4; Lelkes-Felvári and Klötzli 2004; Fig. 1a) and also as dykes within a crystalline limestone quarry near the village of Polgárdi (Fig. 1a).

The age of these occurrences was basically considered on stratigraphic ground. Most of the former radiometric (K-Ar) datings failed to demonstrate their Permian age due to the subsequent diagenetic, metamorphic and/or metasomatic influence. The only Permian zircon $\mathrm{U}-\mathrm{Pb}$ age was published in the ALCAPA Mega-unit (ALCAPA MU) by Lelkes-Felvári and Klötzli (2004), which placed the silicic volcanism to the Early Permian at 291.4 $\pm 4.7 \mathrm{Ma}$. This volcanic episode was also recorded by a detrital zircon age component $(279 \pm 3 \mathrm{Ma})$ of Miocene sediments of the region (Kelemen et al. 2017).

The major goal of this study is to report new petrographic observations, geochemical (whole-rock analysis including major and trace elements), and geochronological (zircon $\mathrm{U}-\mathrm{Pb}$ ages) data to summarize our knowledge on the Permian volcanic activity in the Pannonian Basin. Our study covers the few outcrops and all available subsurface occurrences mainly from the Tisza MU. We further correlate these rocks with other Permo-Carboniferous felsic volcanic rocks of Central Europe (Apuseni Mts, Western Carpathians, NE Germany, Intra-Sudetic Basin).

\section{Geological background}

The Pannonian Basin is a Neogene basin located in eastern Central Europe. Its pre-Neogene basement consists of two mega-units, the Tisza MU and the ALCAPA MU of different geological history. The Tisza MU forms the basement of the Pannonian Basin south of the Mid-Hungarian line and crops out in two main areas in Southern Transdanubia that are the Mecsek and the Villány Mts (Fig. 1). The pre-Neogene basement of the area is known by several boreholes done for uranium ore and hydrocarbon exploration work (Szederkényi et al. 2013). Based on the Alpine evolution of the rocks three main facies zones, the so-called Mecsek, Villány-Bihor, and Békés-Codru Units are distinguished within the Tisza MU (Szederkényi et al. 2013). Permian felsic volcanic rocks showing similar petrographic features appear in all the three Alpine zones and are collectively named Gyûrüfü Rhyolite Formation in the Hungarian lithostratigraphical literature, after the locality of the single outcrop (Fig. 1b), near the village of Gyúrüfú in the Western Mecsek Mts (Fülöp 1994). The most important information (outcrop/boreholes, base, top, thickness, radiometric age data, and facies zones) about the Permian volcanic rocks in Hungary are summarized in Table 1. Previous papers and drilling reports (Fazekas 1978; Barabásné Stuhl 1988; Császár 2005) outlined the main regions, where this formation is present (Fig. 1). These are (1) the Western Mecsek Mts as part of the Mecsek Unit; (2) the Máriakéménd-Báta Basement Range (Máriakéménd-Báta BR) and (3) the northern foreland of the Villány Mts as parts of the Villány-Bihor Unit; (4) the Battonya-Pusztaföldvár Basement Ridge (Battonya-Pusztaföldvár BR) and (5) the Kelebia area belonging to the Békés-Codru Unit.

Most of the interpretations (Szederkényi 1962; Fazekas 1978; Barabásné Stuhl 1988) considered rhyolitic-dacitic lava flows in the drillings and outcrops; however, recently, occurrences in the Western Mecsek Mts were reinterpreted as of pyroclastic origin (Hidasi et al. 2015; Szemerédi et al. 2016). In this area, the small unique outcrop between the villages of Gyúrüfü and Dinnyeberki is represented by rhyolitic ignimbrites (Szemerédi et al. 2016) and numerous boreholes penetrated pyroclastic rocks as well (Fig. 1b). Here, the maximum thickness of the formation is $144.1 \mathrm{~m}$. In the Máriakéménd-Báta BR, the Gyúrúfú Rhyolite was documented by four wells (Fig. 1b) having a maximum thickness of $142.9 \mathrm{~m}$ (borehole Somberek-1). In the northern foreland of the Villány Mts, a complex system of the Permian volcanic rocks (pyroclastic rocks and lavas) is known by deep 
Table 1 Most important information about the studied Permian felsic volcanic rocks of the Tisza Mega-unit and the ALCAPA Mega-unit, Hungary

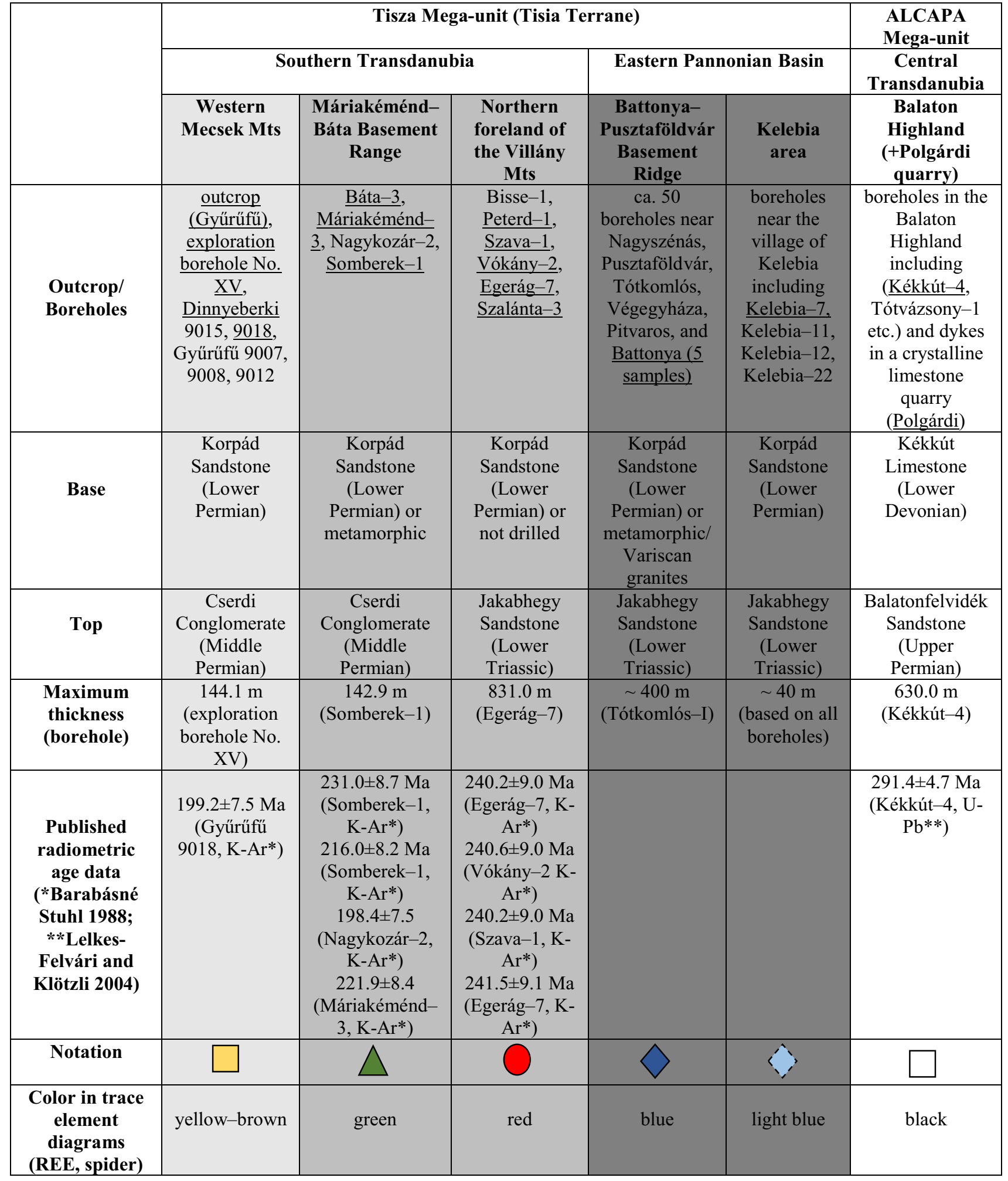

The selected 20 outcrop/boreholes of recent study with whole-rock geochemical data are underlined. Pale grey: Mecsek Unit, grey: VillányBihor Unit, dark grey: Békés-Codru Unit 
drillings (Bisse-1, Egerág-7, Peterd-1, Szalánta-3, Szava-1, and Vókány-2; Fig. 1b) generally having hundreds of meters in thickness (e.g., Bisse-1: $428 \mathrm{~m}$, Egerág-7: $831 \mathrm{~m}$, and Vókány-2: $461 \mathrm{~m}$ ). At the Battonya-Pusztaföldvár BR, eastern Pannonian Basin, the Permian volcanic rocks (dominantly rhyolitic ignimbrites; Szemerédi et al. in press) are penetrated by ca. 50 deep petroleum exploration drillings, their greatest thickness being $\sim 400 \mathrm{~m}$ (borehole TótkomlósI). In the Kelebia area (Fig. 1a), the Permian volcanic rocks are known by 4 boreholes and were affected by Alpine very low-grade metamorphism (Császár 2005; Raucsik et al. 2016).

Upper Paleozoic felsic volcanic rocks also occur in the ALCAPA MU, in the region of Central Transdanubia (Fig. 1a), and are known by several boreholes, dominantly in the Balaton Highland (Fülöp 1990; Table 1). The most studied deep borehole of the area is the well Kékkút-4 (Fig. 1a) that penetrated volcanic rocks with a thickness of $630 \mathrm{~m}$. Strongly altered porphyric lavas of the drilling show dacitic composition and are underlain by Lower Devonian limestones and overlain by Upper Permian continental red beds (Fülöp 1990; Lelkes-Felvári and Klötzli 2004). Dykes having similar composition are also known in the metamorphic limestone quarry near Polgárdi (Fig. 1a), suggesting an extensive volcanic activity during the Permian. The volcanic activity of the ALCAPA MU is considered to be Early Permian and referring to the most significant borehole these rocks are collectively named Kékkút Dacite or 'Kékkút quartz porphyry' in the Hungarian geological literature.

Previous $\mathrm{K}-\mathrm{Ar}$ age data are dominantly Triassic (Balogh and Kovách 1973) which contradicts their stratigraphic position (Table 1). The only radiometric age data (zircon $\mathrm{U}-\mathrm{Pb}$ ) proving Permian age for the volcanic activity are published from a borehole sample (Kékkút-4, 865 m; Lelkes-Felvári and Klötzli 2004) of the ALCAPA MU.

\section{Sampling and analytical methods}

In the Western Mecsek Mts, fresh hand specimens were collected from the outcrops between the villages of Dinnyeberki and Gyưrúfú (Szemerédi et al. 2016). Boreholes exposing felsic volcanic rocks in Southern Transdanubia were drilled by the Mecsek Ore Mining Company during the second half of the twentieth century. Representative volcanic samples were provided by the company from boreholes Bisse-1, Egerág-7, Peterd-1, Szalánta-3, Szava-1, and Vókány-2. In addition, Permian volcanic rocks belonging to the collection of the Department of Petrology and Geochemistry, Eötvös Loránd University (Budapest) from drillings near the villages of Egerág, Peterd, Szava, Vókány, Máriakéménd, and Somberek were also used for petrographic analyses. Several samples representing the Battonya-Pusztaföldvár BR and the Kelebia area were also selected from the core collection of the Department of Mineralogy, Geochemistry and Petrology, University of Szeged.

Petrographic observations were done at the Department of Mineralogy, Geochemistry and Petrology, University of Szeged using Brunel SP-300-P and Olympus BX41 polarizing microscopes. Modal compositions (vol\%) in the petrographic descriptions are estimations from thin sections.

A total of 20 samples were selected for bulk rock chemistry (Supplementary Tables 1-3). These specimens were powdered and analyzed at the Bureau Veritas Mineral Laboratories (AcmeLabs, Vancouver, Canada) by ICP-ES (major elements) and ICP-MS (trace elements including REE). Sample preparation included the splitting of $0.2 \mathrm{~g}$ sample for $\mathrm{LiBO}_{2} / \mathrm{Li}_{2} \mathrm{~B}_{4} \mathrm{O}_{7}$ fusion decomposition for ICP-ES and $0.2 \mathrm{~g}$ sample for ICP-MS. Detection limits for major elements are $0.01-0.04 \mathrm{wt} \%$. The analytical accuracy was controlled using the internal geological reference materials STD SO-19 and QUARTZ_KRA (pure quartz). The accuracy was better than $\pm 1.5 \%$. The precision was verified by duplicated samples in each analytical set. During repeated measurements, it was better than $0.5 \%$. Loss on ignition (LOI) was determined by weight difference after $4 \mathrm{~h}$ ignition at $1000{ }^{\circ} \mathrm{C}$. For comparison, the major and/or trace element geochemistry of the analogous formations of the European Variscides were used from published papers.

Zircon $\mathrm{U}-\mathrm{Pb}$ geochronology were performed on 63-125 $\mu \mathrm{m}$ zircon crystals concentrated by standard heavy mineral separation method (crushing, sieving, heavy liquid separation, magnetic separation, and hand-picking). Zircon crystals were fixed on a double-side adhesive tape and embedded in a $25 \mathrm{~mm}$ diameter epoxy mounts. The crystal mounts were lapped by 2500 mesh $\mathrm{SiC}$ paper and polished by 9,3 , and 1 micron diamond suspensions. Cathodoluminescence mapping was done at the Department of Petrology and Geochemistry, Eötvös Loránd University, Budapest using an AMRAY 1830 scanning electron microscope equipped with a GATAN MiniCL. The in situ U-Pb radiometric age determinations were performed for one sample (Gy-1, Gyúrúfú outcrop) at the ETH, Zürich, Switzerland and five samples at the GÖochron Laboratories of GeorgAugust University, Göttingen, Germany by laser-ablation single-collector sector-field inductively coupled plasma mass spectrometry (LA-SF-ICP-MS). In Göttingen, a Thermo Scientific Element 2 mass spectrometer, while in Zürich, a Thermo Scientific Element XR mass spectrometer was used, both coupled to a Resonetics Excimer laser-ablation system. All age data presented here were obtained by single spot analyses with a laser beam diameter of $33 \mu \mathrm{m}$, a repetition rate of $5 \mathrm{~Hz}$, and an energy density of $2 \mathrm{~J} \mathrm{~cm}^{-2}$ and a crater depth of approximately $10 \mu \mathrm{m}$. Detailed parameters are listed in Electronic Supplementary Material 1. 
Table 2 Compilation of the zircon, in situ geochronological results obtained on the Permian felsic volcanic rocks from the Tisza Mega-unit and the ALCAPA Mega-unit

\begin{tabular}{|c|c|c|c|c|c|}
\hline Sample name & $\begin{array}{l}\text { Concordant/all } \\
\text { spots }\end{array}$ & $\mathrm{Th} / \mathrm{U}(1 \mathrm{SD})$ & TuffZirc age (Ma) & IsoplotR result $^{\mathrm{a}}(\mathrm{Ma})$ & $\begin{array}{l}\text { Interpreted eruption age } \\
\text { (with external errors) }\end{array}$ \\
\hline \multicolumn{6}{|c|}{ Tisza Mega-unit (Tisia Terrane) } \\
\hline \multicolumn{6}{|c|}{ Western Mecsek Mts } \\
\hline Gy-1 & $39 / 45$ & $0.6 \pm 0.4$ & $267.4+0.6-1.4(17)$ & $266.8 \pm 0.2$ & $266.8 \pm 2.7$ \\
\hline \multicolumn{6}{|c|}{ Northern foreland of the Villány Mts } \\
\hline Szava-1 & $29 / 36$ & $0.6 \pm 0.3$ & $266.5+1.2-1.9(14)$ & $265.3 \pm 0.5$ & $265.3 \pm 2.7$ \\
\hline \multicolumn{6}{|c|}{ Battonya-Pusztaföldvár Basement Ridge } \\
\hline BATR/1 & $26 / 31$ & $0.4 \pm 0.1$ & $259.4+0.9-1.5(22)$ & $259.5 \pm 0.4$ & $259.5 \pm 2.6$ \\
\hline BATR/2 & $20 / 35$ & $0.4 \pm 0.1$ & $259.4+2.3-1.8(11)$ & $259.5 \pm 0.5$ & $259.5 \pm 2.6$ \\
\hline \multicolumn{6}{|l|}{ Kelebia area } \\
\hline Kel-7 & $32 / 36$ & $0.3 \pm 0.2$ & $263.7+2.4-0.7(19)$ & $263.4 \pm 0.5$ & $263.4 \pm 2.7$ \\
\hline \multicolumn{6}{|c|}{ ALCAPA Mega-unit (ALCAPA Terrane) } \\
\hline PR-1 & $18 / 35$ & $0.6 \pm 0.2$ & $281.5+2.9-0.6(20)$ & $281.0 \pm 0.5$ & $281.0 \pm 2.9$ \\
\hline
\end{tabular}

${ }^{\text {a }}$ Discordant and outlier data free concordia ages of IsoplotR except for Gy-1 which result stands for the youngest age component of the IsoplotR mixing model

The method employed for analysis in Göttingen is described in detail by Frei and Gerdes (2009). Here, the data reduction is based on the processing of ca. 46 selected time slices (corresponding ca. $13 \mathrm{~s}$ ) starting ca. $3 \mathrm{~s}$ after the beginning of the signal. If the ablation hit zones or inclusions with highly variable actinide concentrations or isotope ratios, then the integration interval was slightly resized or the analysis was discarded ( $\sim 1 \%$ of the spots). The individual time slices were tested for possible outliers by an iterative Grubbs test (applied at $P=5 \%$ level). This test filtered out only the extremely biased time slices, and in this way usually less than $2 \%$ of the time slices were rejected. Drift and fractionation corrections and data reductions were performed by an in-house software (UranOS; Dunkl et al. 2008).

In Zürich, we applied $40 \mathrm{~s}$ ablation duration and no common $\mathrm{Pb}$ correction, but integration intervals were set to exclude inclusions and common $\mathrm{Pb}$. Data were processed using Iolite 2.5 (Paton et al. 2010, 2011) and checked for apparent discordancy using VizualAge (Petrus and Kamber 2012).

In both laboratories, age calculation and quality control are based on the drift- and fractionation correction by standard-sample bracketing using GJ-1 zircon standard reference material (Jackson et al. 2004; "Primary SRM"). For further control the Plešovice, 91500, Temora and LG_0302 standard reference zircons (Wiedenbeck et al. 1995; Black et al. 2004; Sláma et al. 2008) were analysed as "Secondary SRM". The age results of the reference materials were consistently within 2 SE of the published ID-TIMS values (see Electronic Supplementary Material 2). The concordia plots and age spectra were constructed and the ZircAge calculations were done by the software Isoplot/Ex 3.0 (Ludwig 2002) and IsoplotR (Vermeesch 2018). Measurements are considered discordant if the difference between the ${ }^{207} \mathrm{~Pb} /{ }^{235} \mathrm{U}$ and ${ }^{206} \mathrm{~Pb} /{ }^{238} \mathrm{U}$ age was larger than $10 \%$. Discordant ages arise from: common $\mathrm{Pb}$ contamination either from inclusions or cracks, recent $\mathrm{Pb}$-loss or measuring different age domains in the grain leading to mixed ages.

The total external error, estimated to be $\sim 1 \%$ for ${ }^{206} \mathrm{~Pb} /{ }^{238} \mathrm{U}$ ages, and is composed of the uncertainty from (1) the applied corrections, especially the down hole fractionation correction, (2) uncertainty of the decay constants, (3) lacking common $\mathrm{Pb}$ correction, and (4) the uncertainty on the true ${ }^{206} \mathrm{~Pb} /{ }^{238} \mathrm{U}$ ratio of the primary standard GJ-1, and possible uncertainty from matrix effects.

Crystallization ages were calculated with $95 \%$ confidence and total uncertainties are given, including quadratically propagated external error as suggested in Horstwood et al. (2016). The external error corrected ages (here considered as ages closest to volcanic eruptions) are reported in Table 2.

\section{Results and interpretations}

\section{Petrography}

In this chapter, the felsic volcanic rocks of the different outcrops and drillings are briefly described. Representative photomicrographs of the volcanic rocks are shown in Fig. 2 and Supplementary Figure 1.

\section{Tisza Mega-unit (Tisia Terrane)}

Felsic rocks in Southern Transdanubia are dominantly greyish or brownish red/purple, massive, compacted lapilli 
tuffs, rich in mm-cm-sized flattened, deformed pumices and various poorly sorted, fragmented crystals (Fig. 2a, b). The maximum length of the pumices is $80-90 \mathrm{~mm}$, and their elongation ratio is 5-90:1-20 (observed on hand specimens). The crystals (30-45 vol\%) are dominantly resorbed, subhedral quartz (10-20 vol\%, up to $5 \mathrm{~mm}$, Fig. 2b) and altered (argillitized, sericitized, or carbonatized), euhedral or subhedral feldspars (10-25 vol\%, dominantly potassium feldspar, subordinate plagioclase, up to $5 \mathrm{~mm}$, Fig. 2a, c). At the northern foreland of the Villány Mts (borehole Peterd-1) pectinate, macroscopically iridescent K-feldspar (adularia) crystals are also present (Supplementary Figure 1a, b). Mafic components are hematitized or chloritized biotite (1-5 vol\%, up to $2 \mathrm{~mm}$, Fig. 2a, b, d) and strongly altered pyroxene ( $<1 \mathrm{vol} \%$, up to $2 \mathrm{~mm}$, Fig. 2a and Supplementary Figure 1b). As accessory minerals zircon (Supplementary Figure 1a), apatite, rutile, monazite, and xenotime were identified (Szemerédi et al. 2016). Some samples of the northern foreland of the Villány Mts (boreholes Egerág-7 and Szalánta-3) contain tourmaline and subhedral garnet crystals (Fig. 2c; Szemerédi et al. 2017). The rocks are variably foliated (Fig. 2a, b), the foliation being formed on altered, devitrified pumices and glass shards (50-200 $\mu$ m; Fig. 2b-d) that are often replaced by clay minerals. Pumices contain high-temperature crystallization domains on their margins and inside them (HTCD-s: axiolites, spherulites, Fig. 2a; e.g., Breitkreuz 2013).

Pyroclastic rocks were also revealed at the eastern Pannonian Basin, however, some differences were found between them and the lapilli tuffs of S Transdanubia. Samples of the Battonya-Pusztaföldvár BR (Fig. 2e) are crystal-poor (10-25 vol\%), massive, pumice-bearing lapilli tuffs that contain subhedral, resorbed, rarely euhedral quartz (10-15 vol\%, up to $3 \mathrm{~mm}$ ) and altered (argillitized, sericitized, or carbonatized), euhedral or subhedral feldspar crystals (10-15 vol\%, dominantly potassium feldspar, subordinate plagioclase, up to $3 \mathrm{~mm}$ ). As mafic component rarely hematitized biotite ( $<1 \mathrm{vol} \%$, up to $1 \mathrm{~mm}$ ), as accessory mineral zircon crystals are present. The samples dominantly contain flattened, devitrified pumices, and sintered glass shards (Fig. 2e); however, some of them shows felsitic, porphyric texture (lava-like appearance, Szemerédi et al. in press).

Samples from the Kelebia area contain oriented, sericitized pumices (Supplementary Figure 1c) in mm size and various broken, subhedral crystals (15-20 vol\% resorbed quartz, $10-15$ vol $\%$ plagioclase, $~ 5$ vol $\%$ biotite, and altered pyroxene) resembling to the lapilli tuffs of $\mathrm{S}$ Transdanubia in their composition. However, these samples differ from the aforementioned volcanic rocks by having quartz crystals with undulose extinction and deformation lamellae and phenocrysts with symmetric quartz and $\mathrm{K}$-mica pressure shadow (Supplementary Figure 1d).
Felsic lavas were only drilled at the northern foreland of the Villány Mts (boreholes Egerág-7, Szalánta-3, Szava1, and Vókány-2, Fig. 2f). The porphyric (25-30 vol\%) rocks are dominated by subhedral, resorbed, or fragmented quartz (10-15 vol\%, up to $5 \mathrm{~mm}$, Fig. 2f), subhedral, altered (argillitized, sericitized, or carbonatized) potassium feldspar and plagioclase (10-25 vol\%, up to $9 \mathrm{~mm}$ ). Mafic components are faded, hematitized or chloritized, fragmented biotite crystals (1-3 vol\%, up to $2 \mathrm{~mm}$ ). Accessory minerals are zircon, apatite, and opaque phases. The textures are dominantly microholocrystalline or felsitic (Fig. 2f), rarely relict perlitic, spherulitic, or granophyric. Two sequences (boreholes Egerág-7 and Szalánta-3) contain more plagioclase than potassium feldspar and no porphyric quartz. In borehole, Szava-1 $0.5-1 \mathrm{~mm}$-sized clots were observed that dominantly contain zircon, apatite, opaque minerals, carbonate, and muscovite (Supplementary Figure 1e, f).

\section{ALCAPA Mega-unit (ALCAPA Terrane)}

Felsic volcanic rocks from borehole Kékkút-4 are light greyish green lavas with quartz, plagioclase, and strongly altered biotite in a fine-grained completely recrystallized matrix. The groundmass is built up by aggregate of quartz + albite; however, spherulithic textures also occur. At some borehole levels, irregular sericite patches, with rims rich in opaque $\mathrm{Fe}-\mathrm{Ti}$ oxides, could represent former glass shards. The mineralogical composition is dominated by fine-grained quartz, plagioclase (up to $1-2 \mathrm{~cm}$, making up glomeroporphyric texture) and also fine-grained, hematitized biotite crystals. The accessory minerals are apatite, zircon, and monazite, and as xenocrysts, altered, coarse garnet crystals occur. In some levels, pseudomorphs of chlorite after amphiboles are also present. Potassium feldspars are absent probably due to the later replacement by albite (showing chess-board structure).

In the Polgárdi quarry, a $\sim 10 \mathrm{~m}$ thick, almost vertically oriented felsic dyke (Fig. 2g, h) cut the Devonian shallow marine limestone, without visible contact zone. Macroscopically, it is light yellowish or greenish grey/white, fine-grained, non-porous, and homogeneous without any orientation. Few, well visible, isometric quartz phenocrysts $(\sim 0.5 \mathrm{~cm})$ and smaller insignificant rectangular feldspar pseudomorphs appear in it. The porphyric components (10-15 vol\%) are represented by three minerals: (1) strongly resorbed isometric quartz grains (4-5 vol\%, Fig. 2g, h); (2) mostly euhedral feldspars (5-10\% vol\%, Fig. $2 \mathrm{~g}$ ) altered totally to muscovite, calcite and few quartz with thin apatite needles; and (3) pseudomorphs of calcite and muscovite after biotite (Fig. 2g, h). These latter grains contain few secondary opaque minerals and Ti oxides. Few original accessory minerals are the corroded dumpy apatite and zircon and 


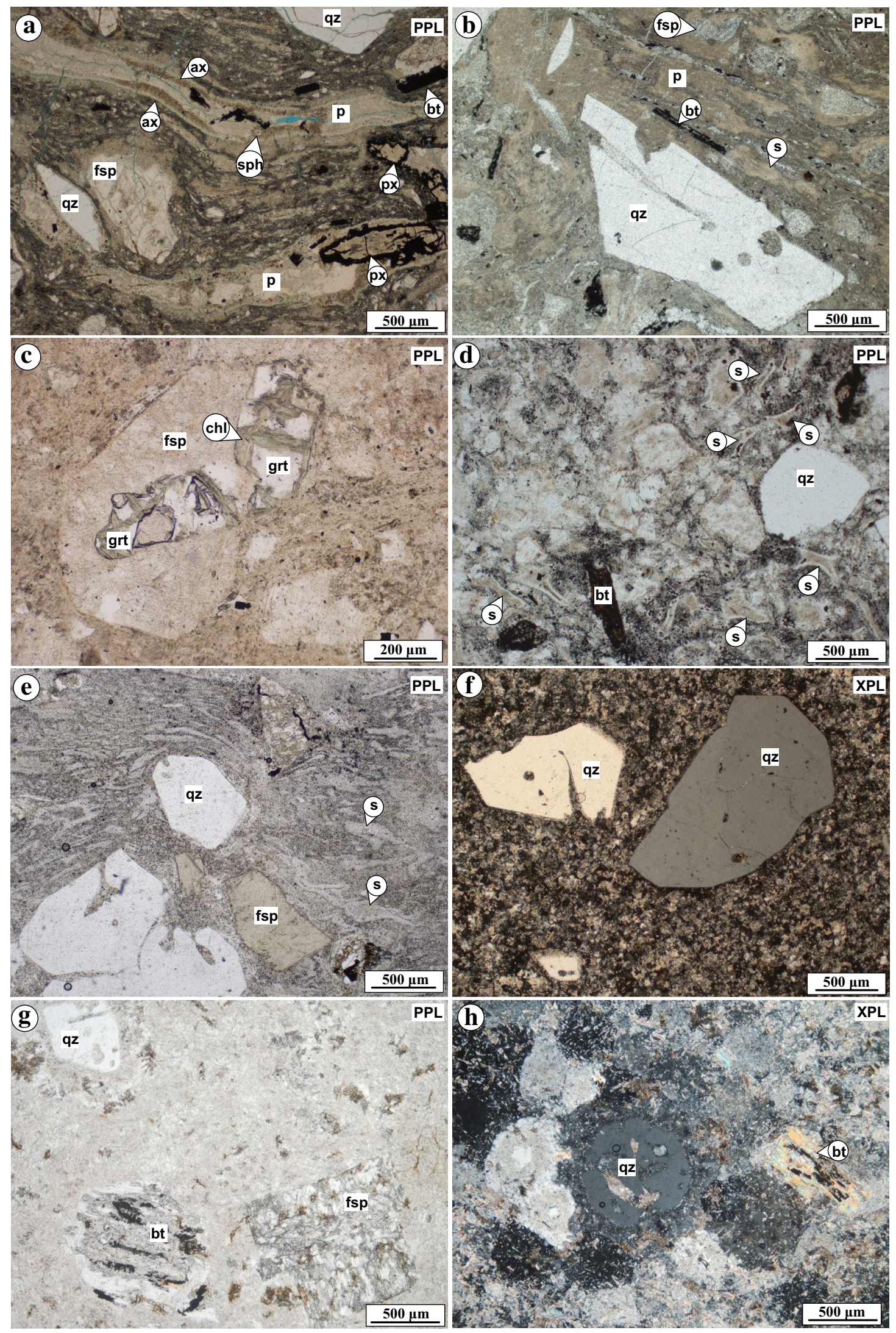


4Fig. 2 Photomicrographs of the Permian felsic volcanic rocks, Tisza Mega-unit and ALCAPA Mega-unit, Hungary: a sample GYRFP, pyroclastite (Western Mecsek Mts, outcrop): parallel pumices with axiolites at the margins and spherulites inside them together with opaque pseudomorphs after pyroxene. b Sample Somberek-1, pyroclastite (Máriakéménd-Báta Basement Range, borehole): fragmented quartz, feldspar and biotite crystals in a welded ignimbrite. c Sample Szalánta-3, pyroclastite (northern foreland of the Villány Mts): subhedral, chloritized and fragmented garnet showing intergrowth with potassium feldspar. d Sample GYR K2, pyroclastite (Western Mecsek Mts, outcrop): X- and Y-shaped glass shards in the matrix of a non-welded ignimbrite. e Sample ÁGK-1830, pyroclastite (BattonyaPusztaföldvár Basement Ridge, borehole): subhedral quartz and feldspar crystals in a strongly welded ignimbrite. f Sample Vókány-2, lava (northern foreland of the Villány Mts, borehole): felsitic texture with subhedral, resorbed and fractured quartz crystals. g Sample Polgárdi, dyke (Central Transdanubia, Polgárdi quarry): porphyric plagioclase and pseudomorph after biotite with resorbed quartz. h Sample Polgárdi, dyke (Central Transdanubia, Polgárdi quarry): mosaic quartz and pseudomorph after biotite in mosaic quartz-sericite groundmass. ax axiolite, bt pseudomorph after biotite, chl chlorite, $f_{s p}$ feldspar, grt garnet, $p$ altered pumice, $p x$ pseudomorph after pyroxene, $q z$ quartz, $s$ altered glass shard, $s p h$ spherulite, $P P L$ plane polarized light, $X P L$ crossed polars

the isometric opaque minerals. The groundmass is secondarily holocrystalline, and filled by mosaic texture of isometric equigranular quartz, overgrown partly on porphyric quartz grains. Few sericite, muscovite, calcite, and siderite are scattered in and between quartz grains.

\section{Major and trace-element geochemistry}

Major and trace, including rare-earth elements, were analyzed for the selected samples of all the five Tisza MU regions and for the studied samples of the ALCAPA MU (Supplementary Tables 1-3). For geochemical comparison compositions of published Permo-Carboniferous felsic volcanic rocks of Central Europe (Apuseni Mts: Nicolae et al. 2014, Intra-Sudetic Basin: Awdankiewicz 1999; Northeast Germany: Paulick and Breitkreuz 2005; Western Carpathians: Vozárová et al. 2009, 2015, 2016); and Permian granites from the Apuseni Mts (Highiş massif, Pál-Molnár et al. 2008) are plotted in the geochemical diagrams. They are completed with the average Palaeozoic felsic volcanic rock composition summarized by Condie (1993).

In the total alkali-silica (TAS) diagram (Fig. 3) based on the new and archive geochemical data (Fazekas 1978; Barabásné Stuhl 1988), most of the samples fall into the rhyolite field with 71.6-77.2 wt $\% \mathrm{SiO}_{2}$ and variable alkali contents (4.0-10.7 wt\%). There is one sample representing the Kelebia area that plots in the trachydacite field and another one from the ALCAPA MU (Kékkút-4 borehole) is dacite according to its major element composition. In the $\mathrm{Zr} / \mathrm{TiO}_{2}$ vs. $\mathrm{Nb} / \mathrm{Y}$ diagram (Fig. 4), since based on trace elements, that are less sensitive for secondary processes, most samples plot in the rhyodacite/dacite and in the rhyolite fields with sub-alkaline character $(\mathrm{Nb} / \mathrm{Y}<0.6)$. In this diagram Fig. 3, outlier samples (Máriakéménd-3, Vókány-2 representing the Tisza MU and the Polgárdi sample representing the ALCAPA MU) fall in the trachyandesite field.

The chondrite-normalized rare-earth element (REE) diagrams (Fig. 5) show different patterns for the samples of the Tisza MU (Fig. 5a) and the ALCAPA MU (Fig. 5b). REE patterns of the studied samples of the Tisza MU are dominantly parallel except for the two outlier samples (Máriakéménd-3, Vókány-2). They usually display enriched light $\left(\mathrm{La}_{\mathrm{N}} / \mathrm{Sm}_{\mathrm{N}}=2.4-3.8\right)$ and near-flat heavy REE $\left(\mathrm{Gd}_{\mathrm{N}} /\right.$ $\left.\mathrm{Yb}_{\mathrm{N}}=1.2-1.7\right)$ patterns with variously deep negative $\mathrm{Eu}$ anomaly $\left(\mathrm{Eu} / \mathrm{Eu}^{*}=0.0-0.3\right.$; Supplementary Tables 1 and $2)$. The values of REE fractionation $\left(\mathrm{La}_{N} / \mathrm{Yb}_{\mathrm{N}}\right)$ change from 3.4 to 9.2. On the other hand, REE patterns of the samples of the ALCAPA MU show slightly higher enrichment in both LREEs $\left(\mathrm{La}_{\mathrm{N}} / \mathrm{Sm}_{\mathrm{N}}=3.3\right.$ and 3.8) and HREEs (Kékkút-4 sample: $\left.\mathrm{Gd}_{\mathrm{N}} / \mathrm{Yb}_{\mathrm{N}}=4.1\right)$. However, their negative Eu anomaly is markedly less significant $\left(\mathrm{Eu} / \mathrm{Eu}^{*}=0.5\right.$ and 0.6 ; Supplementary Table 3) and the Polgárdi sample is depleted in HREEs $\left(\mathrm{Gd}_{\mathrm{N}} / \mathrm{Yb}_{\mathrm{N}}=1.7\right)$. Besides the difference in their Eu anomaly, samples of the Tisza MU show higher enrichment in all the REEs than the samples of the ALCAPA MU show in general. In multi-element spider diagrams (Fig. 5), the samples of the Tisza MU (Fig. 5e) are characterized by enrichment in $\mathrm{Rb}, \mathrm{K}, \mathrm{Th}$, and $\mathrm{U}$ and depletion in $\mathrm{Ba}, \mathrm{Nb}, \mathrm{Sr}, \mathrm{P}$, and $\mathrm{Ti}$. The two outlier samples (Vókány-2, Máriakéménd-3) have remarkably different REE concentrations with extremely low $\Sigma$ REE values (22 and 36, respectively) and they show relative depletion in other immobile elements ( $\mathrm{Ti}, \mathrm{Y}, \mathrm{Zr}$ ), too. The samples from the ALCAPA MU (Fig. 5f) differ from the volcanic rocks of the Tisza MU by showing no depletion in $\mathrm{P}$ and slighter depletion in Ti. The Polgárdi sample also shows relative depletion to the Kékkút core sample not only in HREEs, but also in immobile elements (Hf, Sm, Ti, Y). All samples show enrichment in $\mathrm{Rb}$ and $\mathrm{Th}$ relative to $\mathrm{Ba}$.

\section{Geochronology}

All studied zircons (Electronic Supplementary Material 3) show weak cathodoluminescence intensity and badly developed oscillatory zoning. 31-45 spots were analyzed in the 6 samples representing the 5 studied areas (Table 2; Electronic Supplementary Material 2). The laser ablation spots are placed mostly in the mantle parts of zircon crystals avoiding cracks and inclusions. The data were filtered out, as they give more than $10 \%$ discordance between ${ }^{206} \mathrm{~Pb} /{ }^{238} \mathrm{U}$ and ${ }^{207} \mathrm{~Pb} /{ }^{235} \mathrm{U}$ ages. The remained dates usually give large age ranges, suggesting the presence of older cores and/or possible $\mathrm{Pb}$ loss. For interpretations, we use the ${ }^{206} \mathrm{~Pb} /{ }^{238} \mathrm{U}$ ages, which are less influenced by small amounts of common $\mathrm{Pb}$ and are calculated from higher intensities of daughter isotopes than in case of ${ }^{207} \mathrm{~Pb} /{ }^{235} \mathrm{U}$ and ${ }^{208} \mathrm{~Pb} /{ }^{232} \mathrm{Th}$ ages. 

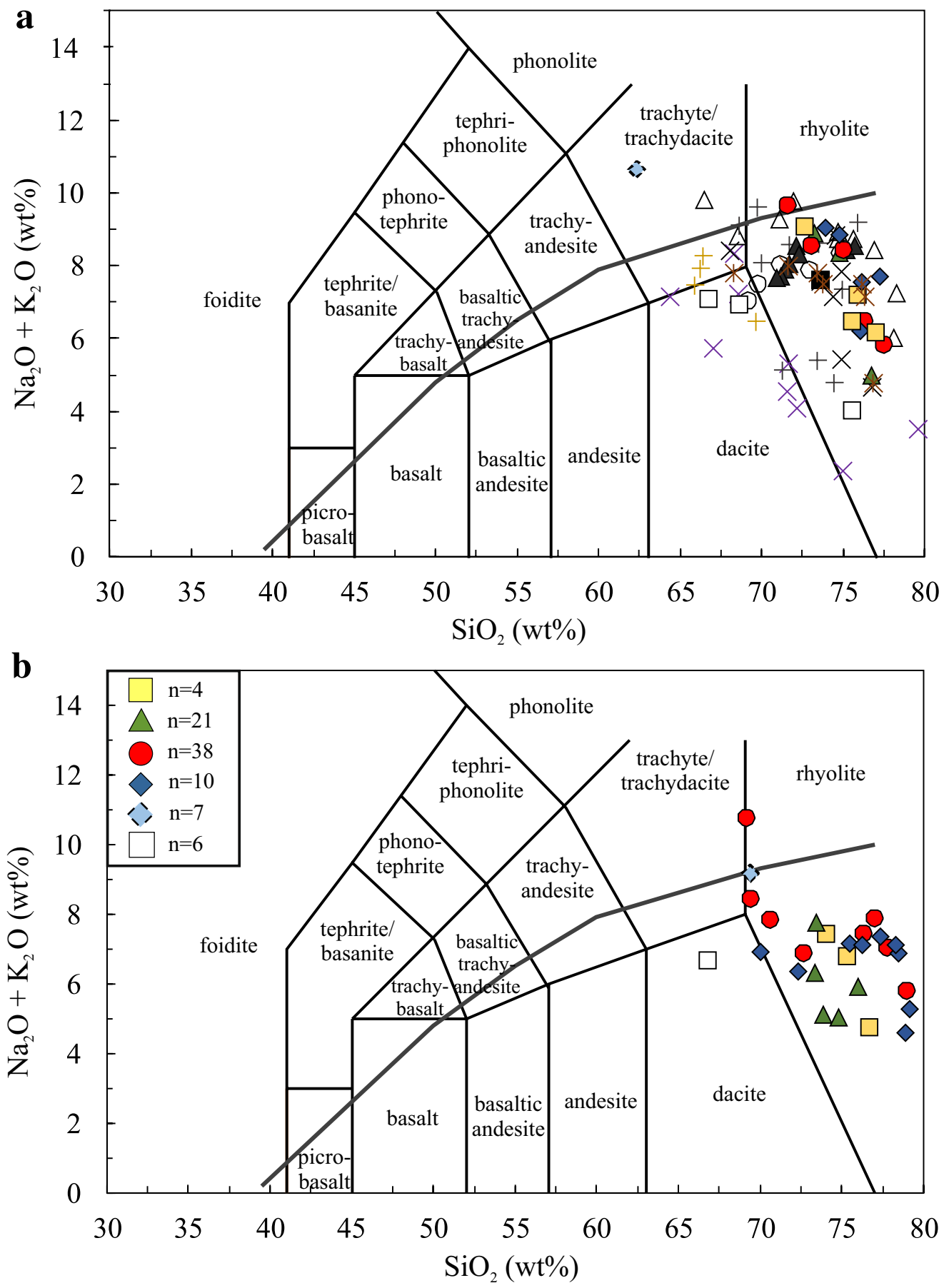

\begin{tabular}{|lllll|}
\hline \multicolumn{1}{|c|}{ Tisza Mega-unit (HU) } & $\square$ & $\begin{array}{c}\text { ALCAPA Mega-unit } \\
\text { (Central Transdanubia, HU) }\end{array}$ & $\triangle$ Intra-Sudetic Basin (PL), younger \\
$\square$ & Western Mecsek Mts & $*$ & Apuseni Mts (RO), Tisza Mega-unit & $\bigcirc$ Intra-Sudetic Basin (PL), older \\
$\triangle$ & Máriakéménd-Báta BR & $\times$ & Northern Gemeric Unit (SK) & + Northeast Germany (D) \\
$\bigcirc$ & Northern foreland of the Villány Mts & & Highiş massif (RO), granites \\
$\diamond$ & Battonya-Pusztaföldvár BR & $\times$ & Southern Gemeric Unit (SK) & Average Palaeozoic felsic \\
\. & Kelebia area & + & Northern Veporic Unit (SK) & \\
\hline
\end{tabular}


4Fig. 3 Classification of the Permian volcanic rocks of the Tisza Mega-unit, the ALCAPA Mega-unit, Hungary and the analogous formations of the European Variscides in total alkali-silica (TAS) diagrams (Le Maitre et al. 1989), based on new (a) and archive (b) geochemical data (Fazekas 1978; Barabásné Stuhl 1988; Fülöp 1990, 1994) with the number of the previous geochemical analyses $(n)$. Comparative data derive from the following authors: Apuseni Mts: felsic volcanic rocks (Nicolae et al. 2014); Northern Gemeric Unit: rhyolites-dacites (Vozárová et al. 2015); Southern Gemeric Unit: rhyolites (Vozárová et al. 2009); Northern Veporic Unit: volcanic rocks and tonalite dyke (Vozárová et al. 2016); Intra-Sudetic Basin: felsic rocks, younger and older volcanic suites (Awdankiewicz 1999); Northeast Germany: rhyodacites (Paulick and Breitkreuz 2005); Highiş massif, Apuseni Mts: Păulis Granites (Pál-Molnár et al. 2008); average Palaeozoic felsic volcanic rock composition: Condie (1993)

They have an average $2 \mathrm{~s}$ uncertainty between 1.5 and $2.4 \%$. $\mathrm{The} \mathrm{Th} / \mathrm{U}$ ratios within samples usually do not give any systematic relation with the ${ }^{206} \mathrm{~Pb} /{ }^{238} \mathrm{U}$ ages.

We applied the TuffZirc Age algorithm of ISOPLOT (Ludwig 2002) on the ${ }^{206} \mathrm{~Pb} /{ }^{238} \mathrm{U}$ ages for selecting the youngest coherent age group, which we may consider as ages closest to the volcanic eruption ages of the samples. However, as the analysed zircon crystals have not passed the annealing procedure (Mattinson 2005) suggested by, e.g., von Quadt et al. (2016) and Sliwinski et al. (2017), the obtained youngest age components can be skewed to younger ages by unidentified $\mathrm{Pb}$-loss effected data. We also approached the eruption ages using IsoplotR (Vermeesch 2018), which resulted similar concordia or youngest peak ages (Table 2; Electronic Supplementary Material 4).

\section{Tisza Mega-unit (Tisia Terrane)}

From the Western Mecsek Mts (Gyúrüfú outcrop), 44 spot analyses prove to be concordant out of the 50 analyzed and they give $0.6 \pm 0.4(1 \mathrm{SD})$ average $\mathrm{Th} / \mathrm{U}$ ratio. The TuffZirc Age algorithm selects 17 date for the youngest coherent age (267.4 +0.6 and - 1.4 Ma; Fig. 6a) excluding 15 older single spot ages, which are possibly affected by the incorporation of much older cores. The IsoplotR concordia age calculation (Electronic Supplementary Material 4) also suggests strongly overdispersed dates that may have geological meaning, i.e., they refer to mixing ages between young (near eruption) and old antecrystic or xenocrystic cores or crystals parts. Such age mixing can be resolved by the mixing model calculation implemented in IsoplotR and the youngest age component was accessed by the younger distinct age of a two component mixing. The youngest age component integrates $80 \%$ of the selected data and gives $266.8 \pm 0.2 \mathrm{Ma}$. The interpreted eruption age of this sample is $266.8 \pm 2.7 \mathrm{Ma}$ taking into account the external errors (Table 2).

The northern foreland of the Villány Mts is represented by the Szava-1 sample. In this sample, 29 zircon spots out of 36 give concordant dates, which vary between 580 and
$217 \mathrm{Ma}$, with mean $\mathrm{Th} / \mathrm{U}$ ratios of $0.6 \pm 0.3$ (1 SD). Fourteen ages give a coherent group referring to $266.5+1.2-1.9 \mathrm{Ma}$ crystallization age (Fig. 6b), the 8 younger dates might be affected by $\mathrm{Pb}-$ loss and 4 data give much older crystallization dates, i.e., 580-367 Ma. These oldest, outlier ages refer to spots which are either cores or show different CL images than most of the crystals. Concordia age calculations by IsoplotR resulted $265.3 \pm 0.5 \mathrm{Ma}(n=17)$ using outlier (outliers were selected by the modified Chauvenet outlier detection criterion of IsoplotR) and discordant free datagroup (Electronic Supplementary Material 4). The interpreted eruption age of this sample is $265.3 \pm 2.7$ Ma taking into account the external errors (Table 2).

From the Battonya-Pusztaföldvár BR, two samples were dated (BATR/1 and BATR/2), representing the Tótkomlós$\mathrm{K}-3$ borehole in the depth of 1669-1674 m. Concordant ages are calculated for 26 and 20 spots out of the analyzed 31 and 35 for BATR/1 and BATR/2 samples, respectively. In both cases, the zircons have $\mathrm{Th} / \mathrm{U}$ ratios around $0.4 \pm 0.1$ (1 SD). BATR/1 sample has a weighted mean age of $259.6 \pm 1.1 \mathrm{Ma}$ with an MSWD of 2.1. The TuffZirc Age of this sample gives similar $259.4+0.9-1.5$ Ma taking 22 spot analyses (Fig. 6c). BATR/2 sample gives identical TuffZirc Age of $259.4+2.3-1.8 \mathrm{Ma}$ (Fig. $6 \mathrm{~d}$ ) to BATR/1 suggesting their common formation age and eruptive unit, although using much less useful data (11). Concordia age calculations by IsoplotR resulted $259.5 \pm 0.4 \mathrm{Ma}(n=22)$ and $259.5 \pm 0.5 \mathrm{Ma}$ $(n=20)$ using outlier and discordant free datagroups (Electronic Supplementary Material 4). The interpreted eruption age of these two samples is $259.5 \pm 2.6$ Ma taking into account the external errors (Table 2).

In the Kelebia- 7 borehole, sample 36 spots were targeted and 32 give concordant ages, with two younger outliers. $\mathrm{Th} / \mathrm{U}$ ratios are around $0.3 \pm 0.2(1 \mathrm{SD})$. TuffZirc Age is $263.7+2.4-0.7$ Ma calculated from 19 dates (Fig. 6e), which is nearly the same as the weighted mean age $(263.5 \pm 2.4 \mathrm{Ma})$ of 25 dates excluding four outliers, with an MSWD 4.5. Four younger dates were ruled out by the algorithm which is in accordance with the fact that these spots have the highest $U$ contents and, therefore, possibly prone to the most Pb-loss. Three spots yielded much older ages, giving evidence for the inheritance of crystals during magma evolution in the crust. IsoplotR resulted $263.4 \pm 0.5 \mathrm{Ma}$ $(n=24)$ as concordia age for the outlier and discordant-free datagroup (Electronic Supplementary Material 4). The interpreted eruption age of this sample is $263.4 \pm 2.7$ Ma taking into account the external errors (Table 2).

\section{ALCAPA Mega-unit (ALCAPA Terrane)}

PR-1 sample is from the Polgárdi outcrop, representing the only known surface occurrence of Permian rhyolite in the ALCAPA MU. Thirty-five spots were measured, but only 18 
Fig. 4 Classification of the studied Permian volcanic rocks of the Tisza Mega-unit, the ALCAPA Mega-unit, Hungary and the analogous formations of the European Variscides in the $\mathrm{Zr} / \mathrm{TiO}_{2}$ vs. $\mathrm{Nb} / \mathrm{Y}$ diagram (Winchester and Floyd 1977). The references of the comparative data are the same as those in Fig. 3

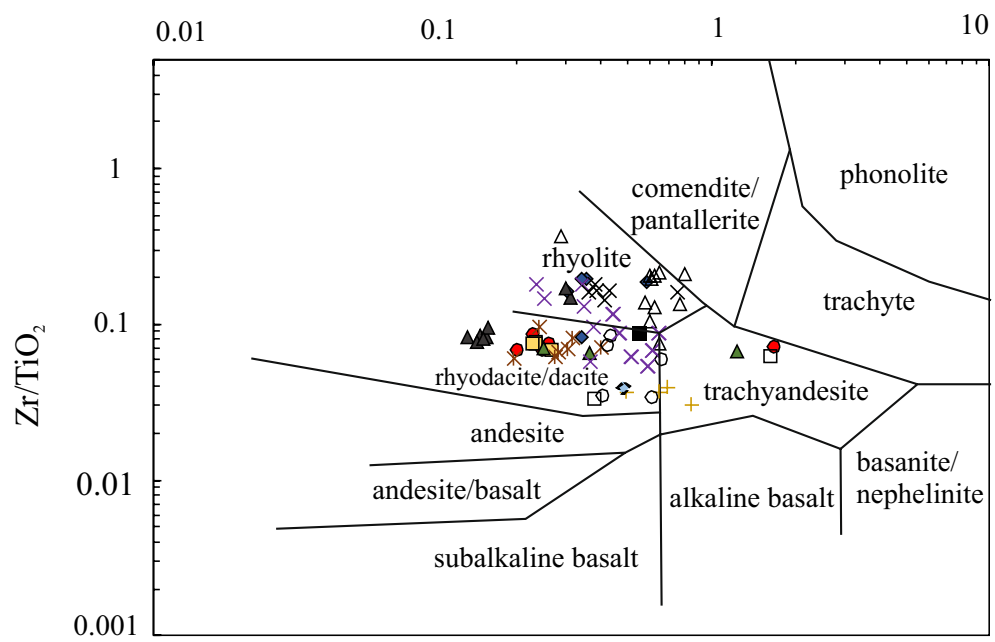

$\mathrm{Nb} / \mathrm{Y}$

\begin{tabular}{|c|c|c|c|}
\hline Tisza Mega-unit (HU) & & $\begin{array}{c}\text { ALCAPA Mega-unit } \\
\text { (Central Transdanubia, HU) }\end{array}$ & $\triangle$ Intra-Sudetic Basin (PL), younger \\
\hline Western Mecsek Mts & & & Intra-Sudetic Basin (PL), older \\
\hline Máriakéménd-Báta BR & * & Apuseni Mts (RO), Tisza Mega-unit & + Northeast Germany (D) \\
\hline Northern foreland of the Villány Mts & $x$ & Northern Gemeric Unit (SK) & Highis massif (RO), granites \\
\hline Battonya-Pusztaföldvár BR & X & Southern Gemeric Unit (SK) & \\
\hline Kelebia area & 1 & Northern Veporic Unit (SK) & alacozor \\
\hline
\end{tabular}

proved to be concordant. These spots have $0.6 \pm 0.2$ (1 SD) average $\mathrm{Th} / \mathrm{U}$ ratio and ages varying between 294 and $272 \mathrm{Ma}$ except for the one with an outlier old core date of $876 \pm 11$ Ma. Twelve spots give a $281.5+2.9-0.6$ Ma TuffZirc Age (Fig. 6f). IsoplotR resulted $281.0 \pm 0.5 \mathrm{Ma}(n=12)$ as concordia age for the outlier and discordant free datagroup (Electronic Supplementary Material 4). The interpreted eruption age of this sample is $281.0 \pm 2.9$ Ma taking in account the external errors (Table 2).

\section{Discussion and interpretations}

Permian felsic volcanic rocks in Hungary occur in two mega-units of different geological histories that are the Tisza MU and the ALCAPA MU. The Tisza MU is dominantly represented by felsic pyroclastic rocks, while lavas are subordinate and present only within the northern foreland of the Villány Mts (Szemerédi et al. 2016, 2017). Felsic volcanic rocks of the ALCAPA MU are represented by lavas and dykes that occur in the Central Transdanubian region and known from boreholes and outcrops. The presence of Permian volcanic rocks within the two terranes suggests two distinct volcanic events which are discussed below. In the following subsections the genetic interpretation of the felsic volcanic rocks, the geochemical character of these significantly altered rocks, the aspects of magma generation, their radiometric age data and the potential regional correlations are discussed.

\section{Genetic interpretations based on petrography and whole-rock geochemistry}

Felsic pyroclastic rocks in Southern Transdanubia (Western Mecsek Mts, Máriakéménd-Báta BR, northern foreland of the Villány Mts) are rhyolitic in composition according to their mineralogical assemblage. The unsorted, massive appearance suggests pyroclastic flow (ignimbrite) origin. Ignimbrites with eutaxitic texture (Fig. 2a, b) indicates high-temperature plastic deformation of the vitroclasts (both pumice and glass shards). Incipient to strong welding is indicated by the flattened pumices and sintering glass shards that determines the foliation of the rocks (e.g., Gifkins et al. 2005). Lapilli tuffs from the Battonya-Pusztaföldvár BR (eastern Pannonian Basin) are crystal-poor (10-25 vol\%) welded ignimbrites (Fig. 2e) with rhyolitic composition lacking mafic components (e.g., altered pyroxene and biotite). Some of these rocks were affected by such a pervasive groundmass crystallization that their primary texture was completely overprinted, creating lava-like ignimbrites with felsitic texture (Szemerédi et al. in press). In pyroclastic samples of the Kelebia area quartz crystals having undulose extinction and deformation lamellae and phenocrysts with symmetric quartz and K-mica pressure shadow (Supplementary Figure 1d) suggest that these rocks were affected by very low-grade metamorphism (e.g., Raucsik et al. 2016). The continuous, coherent bands of sericite are interpreted as a space foliation (Supplementary Figure 1c) due to ductile 
shortening. According to the primary composition and textural features, these rocks are rhyodacitic ignimbrites.

Microholocrystalline or felsitic (Fig. 2d), rarely relict perlitic, spherulitic, or granophyric textures of felsic lavas from the northern foreland of the Villány Mts, represents a wide range of rhyolitic lava/dome lithofacies (microcrystalline core, perlitic core, and brecciated variations of them as parts of the outer carapace; Szepesi et al. 2016; Szemerédi et al. 2017). Two sequences (boreholes Egerág-7 and Szalánta-3) with more plagioclase than potassium feldspar and no porphyric quartz suggest dacitic composition. Clots of zircon, apatite, opaque minerals, carbonate, and muscovite (Supplementary Figure 1e, f) suggest hydrothermal influence.

According to the mineralogical composition and the textural features, the rocks of the Kékkút-4 borehole are dacitic lavas. Subvolcanic dykes with similar mineralogical composition were found in the Devonian limestone quarry of Polgárdi (Fig. 2g, h) most probably representing the same magmatic system.

In case of some samples, their geochemical classification differ from the petrographic interpretation based on the major mineral assemblage, and all results are compared in Table 3. Although in the TAS diagrams (Fig. 3), most of the samples plot in the rhyolite field, the immobile trace elements (in the $\mathrm{Zr} / \mathrm{TiO}_{2}$ vs. $\mathrm{Nb} / \mathrm{Y}$ diagram, Fig. 4) show dominantly rhyodacitic/dacitic composition. This might indicate significant post-magmatic changes in the major element compositions (e.g., $\mathrm{SiO}_{2}$ gain, $\mathrm{Na} / \mathrm{K}$-metasomatism) except for the Kékkút-4 sample of the ALCAPA MU which proves to be relatively less altered. Thus, immobile element-based rock classifications $\left(\mathrm{Zr} / \mathrm{TiO}_{2}\right.$ vs. $\left.\mathrm{Nb} / \mathrm{Y}\right)$ were accepted, suggesting rhyodacitic/dacitic composition for the majority of the samples, which is in agreement with their major mineral assemblage and with the crystal-rich character (in case of dacites) of the rocks. The latter ones comprise mostly ignimbrites with variable degrees of welding and possibly, these rocks of Southern Transdanubia and the Kelebia area could represent the so-called crystal-rich monotonous intermediates (e.g., Hildreth 1981). The crystal-poor and quartzdominated samples of the Battonya-Pusztaföldvár BR show rhyolitic immobile trace-element character; thus, they are interpreted to be rhyolites and could represent the crystalpoor, melt-dominated silicic volcanic rocks (e.g., Hildreth 1981; Huber et al. 2012). Felsic effusive rocks from the Kékkút-4 borehole (ALCAPA MU) are less altered and show dacitic composition both in major and trace-element-based classification diagrams (Table 3 ).

\section{Post-magmatic alterations}

The major element geochemistry is clearly showing the alteration effects which is characteristic for other Permian volcanic series (Paulick and Breitkreuz 2005; Nicolae et al. 2014; Vozárová et al. 2009, 2015, 2016). Effects of $\mathrm{K}$-metasomatism are indicated by the high potassium/total alkali ratio, $\mathrm{K}_{2} \mathrm{O}(\mathrm{wt} \%) /\left[\mathrm{Na}_{2} \mathrm{O}(\mathrm{wt} \%)+\mathrm{K}_{2} \mathrm{O}(\mathrm{wt} \%)\right] \times 100$, that is higher than 90 in case of six samples and most of the samples lie outside the igneous spectrum (Hughes 1973). The $\mathrm{Na}_{2} \mathrm{O} / \mathrm{Al}_{2} \mathrm{O}_{3}$ vs. $\mathrm{K}_{2} \mathrm{O} / \mathrm{Al}_{2} \mathrm{O}_{3}, \mathrm{Na}_{2} \mathrm{O} / \mathrm{K}_{2} \mathrm{O}$ vs. $\mathrm{SiO}_{2} /$ $\mathrm{Al}_{2} \mathrm{O}_{3}$ (Garrels and Mackenzie 1971; Fig. 7a, b) and $\mathrm{Na}_{2} \mathrm{O}$ vs. $\mathrm{K}_{2} \mathrm{O}$ diagrams (Paulick and Breitkreuz 2005; Fig. 7c) clearly show the alteration effects on the whole-rock geochemistry. Both K-metasomatism (adularization) and albitization were suggested in the previous reports of uranium ore exploration (Fazekas 1978; Barabásné Stuhl 1988; based on petrographic and geochemical observations). This was confirmed by recent studies based on the petrography of samples of Southern Transdanubia and by XRD analyses of separated feldspar crystals that showed the existence of adularia (Szemerédi et al. 2016, 2017). K-metasomatism or albitization are general features of the other Permian felsic volcanic rocks in the European Variscides (Awdankiewicz 1999; Paulick and Breitkreuz 2005; Vozárová et al. 2015, 2016; Szemerédi et al. 2016, 2017).

The Máriakéménd-3 and Vókány-2 samples are outliers with their extremely low immobile trace-element compositions (including REE, U, Th, Y, and Zr, Fig. 5), suggesting the mobilization of these elements. The mobility could be associated with hydrothermal fluids that might have leached these elements from accessory minerals, particularly from fractured and/or metamict zircon or apatite, monazite, and xenotime (e.g., Rubin et al. 1993; Jiang et al. 2004; René 2014). Petrographic observations revealed the scarcity in zircon and other accessory minerals, a possible sign of hydrothermal alteration. Mobility of REE, U, Th, Y, and Zr is most common, but not restricted to F-rich hydrothermal solutions related to alkali igneous suites (Rubin et al. 1993). Formation of uranium ore deposits is often associated with the mobility of these immobile elements (René 2014). Uranium mineralization is known in the Western Mecsek Mts, close to the outcrop of the Gyúrúfú Rhyolite (Dinnyeberki uranium ore deposit, Vincze et al. 2011; Konrád et al. 2012). On the other hand, hydrothermal sulfidic mineralization (related to dykes filled with quartz, pyrite, siderite, hydromuscovite, hematite, chalcopyrite etc.; Fazekas and Vincze 1991) is also known from levels of the Szava-1 borehole in the northern foreland of the Villány Mts and presumably formed due to the interaction of the felsic volcanic (host) rock with hydrothermal fluids. These local ore formations could be the feasible sites of accumulation of the immobile elements leached from Permian volcanic rocks represented by the Máriakéménd-3 and Vókány- 2 drill cores.

Partially similar depletion trends characterize the Polgárdi sample that shows depletion in heavy REEs and in many other immobile elements (including $\mathrm{Hf}, \mathrm{Zr}$, and $\mathrm{Y}$ ) and remarkedly higher depletion in $\mathrm{Ba}, \mathrm{Sr}$, and $\mathrm{Ti}$ compared to 

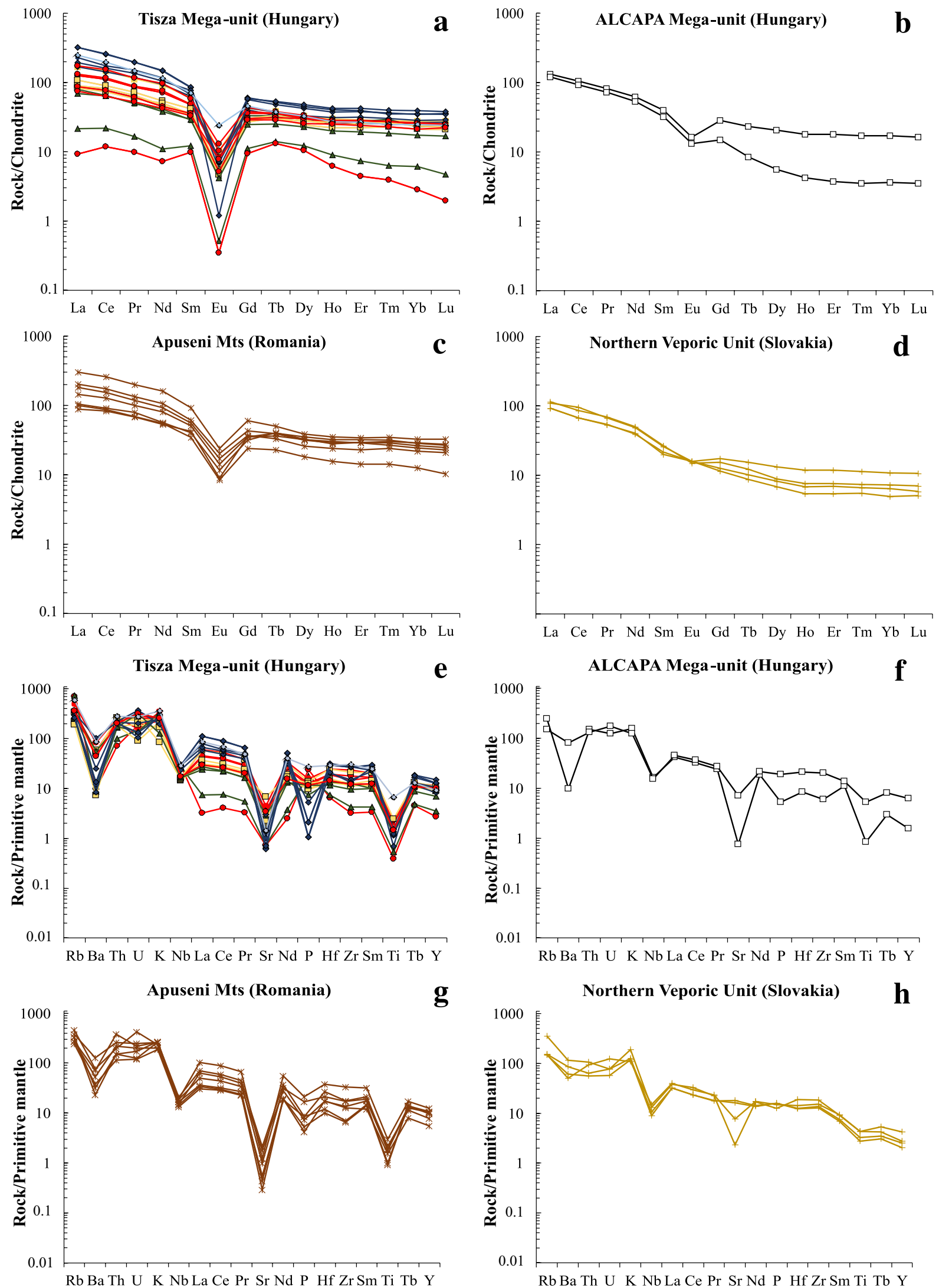

\section{g}

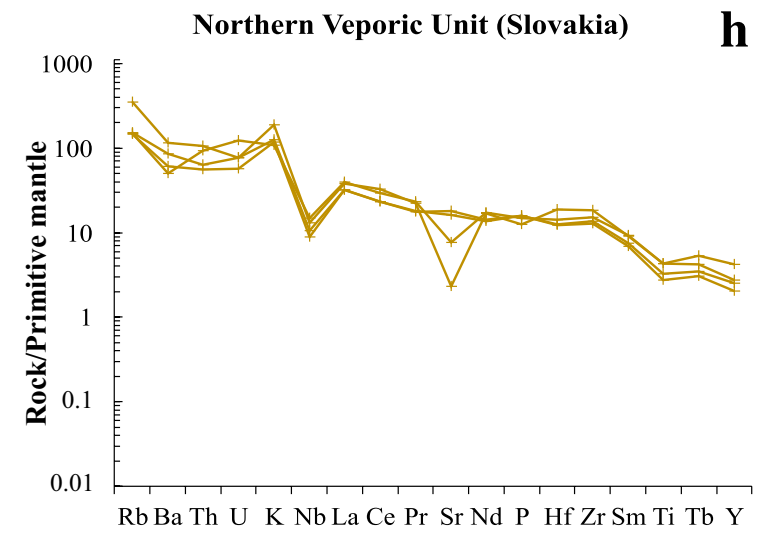


4Fig. 5 Chondrite-normalized rare earth element (REE) patterns and multi-element spider diagrams (Sun and McDonough 1989) of the Permian volcanic rocks of the Tisza Mega-unit, the ALCAPA Megaunit, Hungary and two of the analogous formations of the European Variscides (Apuseni Mts, Romania and Northern Veporic Unit Slovakia; Nicolae et al. 2014; Vozárová et al. 2016). The latter play important role in the regional correlation (see details in "Geochronology and correlation"). Note fractionated light (L)REE, negative Eu anomaly and nearly flat heavy (H)REE pattern. The symbols are the same as those in Fig. 3

the less altered Kékkút core from the ALCAPA MU. Lower values of these immobile elements in the rocks might be due to weathering processes of accessory minerals that have been accumulated them before (e.g., garnet and monazite). On the other hand, it is also possible that the volcanic rocks of the Kékkút-4 borehole ( 291 Ma; Lelkes-Felvári and Klötzli 2004) and the younger ( $281 \mathrm{Ma})$ dacitic dykes in the Polgárdi quarry represent two distinct volcanic episodes of a long-lasting magmatism thus they bear slighter geochemical differences. The three altered samples (Máriakéménd-3, Vókány-2, Polgárdi) are not used for magmatic interpretations.

\section{Tectonic implications and the potential source of the magmatism}

Silicic volcanic rocks could occur in various tectonic settings. Pearce et al. (1984) suggested a set of diagrams to discriminate them, where the $\mathrm{Y}-\mathrm{Nb}$ plot (Fig. 8a) seems to be the less affected by secondary alteration. Rhyodacitic/dacitic rocks of the Western Mecsek Mts, the Máriakéménd-Báta BR and the northern foreland of the Villány Mts fall into the border between the volcanic-arc and the within-plate-granite fields, while the rhyodacitic/dacitic samples of the Kelebia area and rhyolitic rocks of the Battonya-Pusztaföldvár BR all plot in the within plate-granite field. On the other hand, the dacitic sample of the ALCAPA MU (Kékkút-4) falls into the volcanic-arc granite field. Similar discrimination diagram was introduced by Gorton and Schandl (2000) using $\mathrm{Ta}, \mathrm{Th}$, and $\mathrm{Yb}$ in which the samples generally plot in the active continental margins field (Fig. 8b). REE patterns are also useful tools for tectonic implications in case of silicic volcanic and plutonic rocks (Christiansen 2005; Bachmann and Bergantz 2008; Christiansen and McCurry 2008). Hotdry-reduced magmas with their characteristic 'seagull' pattern (deep negative Eu anomaly) are formed in the areas of mantle upwelling (hotspots and continental rifts), while cold-wet-oxidized magmas (with insignificant negative $\mathrm{Eu}$ anomaly) are found in subduction zones (Christiansen 2005; Bachmann and Bergantz 2008; Christiansen and McCurry 2008). All samples of the Tisza MU show 'seagull' pattern suggesting hot-dry-reduced magmas, while REE patterns of the ALCAPA MU refer to cold-wet-oxidized magmas.
REE patterns also correspond with the mafic mineral assemblages: pseudomorphs after anhydrous pyroxene occur in most of the samples of the Tisza MU, while hydrous amphiboles (pseudomorphs) were observed only in the samples of the Kékkút-4 borehole (ALCAPA MU). This bimodal magmatectonic character can be explained by a post-collisional tectonic regime as described from various parts of the European Variscides (Awdankiewicz 1999; Wilson et al. 2004; Nicolae et al. 2014; Vozárová et al. 2015; Repstock et al. 2017, etc.).

Trace element and REE patterns of the samples of the Tisza MU show significant similarity with the felsic volcanic rocks of the Apuseni Mts, Romania (Nicolae et al. 2014; Fig. 5) implying a possible common origin. However, in the $\mathrm{La}_{N} / \mathrm{Yb}_{\mathrm{N}} \mathrm{vs} . \mathrm{La}_{\mathrm{N}}$ diagram (Fig. 8c), they show slightly different trends. Felsic rocks from the Tisza MU follow a linear positive trend that could be explained by fractional crystallization involving possibly garnet and/or zircon. Some pyroclastic rocks of the Villány Mts (Egerág-7 and Szalánta-3 boreholes) contain garnet crystals. Garnets are rare primary mineral phase in intermediate and silicic igneous rocks and are formed either in the early stage of magma evolution from hydrous magma at high pressure (Harangi et al. 2001), or in certain cases, they could be also late stage crystallization products. Although mafic-intermediate rocks are not known in the territory of Hungary, contrary to the Apuseni Mts, where basaltic and subordinate andesitic lavas are present (Nicolae et al. 2014), the Permian volcanic activity resulting in felsic rocks could have occurred close to each other. Nicolae et al. (2014) used Sr-Nd isotope geochemistry and supposed the magma generation within the lower crust due to emplacement of mantle-derived magmas that provided heat to partial melting. Although pure anatexis of crustal material to yield large volume of silicic magma is thermally not favourable, in the magma evolution, we cannot exclude significant contribution from the crust as an assimilation combined with fractional crystallization (AFC) process.

Further geochemical similarity between the samples of the Tisza MU and the Permian rhyolitic ignimbrites of the Southern Gemeric Unit (SGU; Western Carpathians, ALCAPA MU; Vozárová et al. 2009), was also observed based on the immobile trace-element composition. In the $\mathrm{Zr} / \mathrm{TiO}_{2}$ vs. $\mathrm{Nb} / \mathrm{Y}$ diagram (Fig. 4), samples of the SGU plot close to the rhyolites of the Battonya-Pusztaföldvár BR and their chondrite-normalized REE and trace element distributions (SGU: not shown in this study, see details in Vozárová et al. 2009) show very similar pattern. Furthermore, there are also Permian granites in the Highiş massif (Apuseni Mts; Pană et al. 2002; Pál-Molnár et al. 2008) that have similar geochemical character. Although the close plutonic-volcanic connection demands further detailed investigation, it is plausible to assume some relationships. 

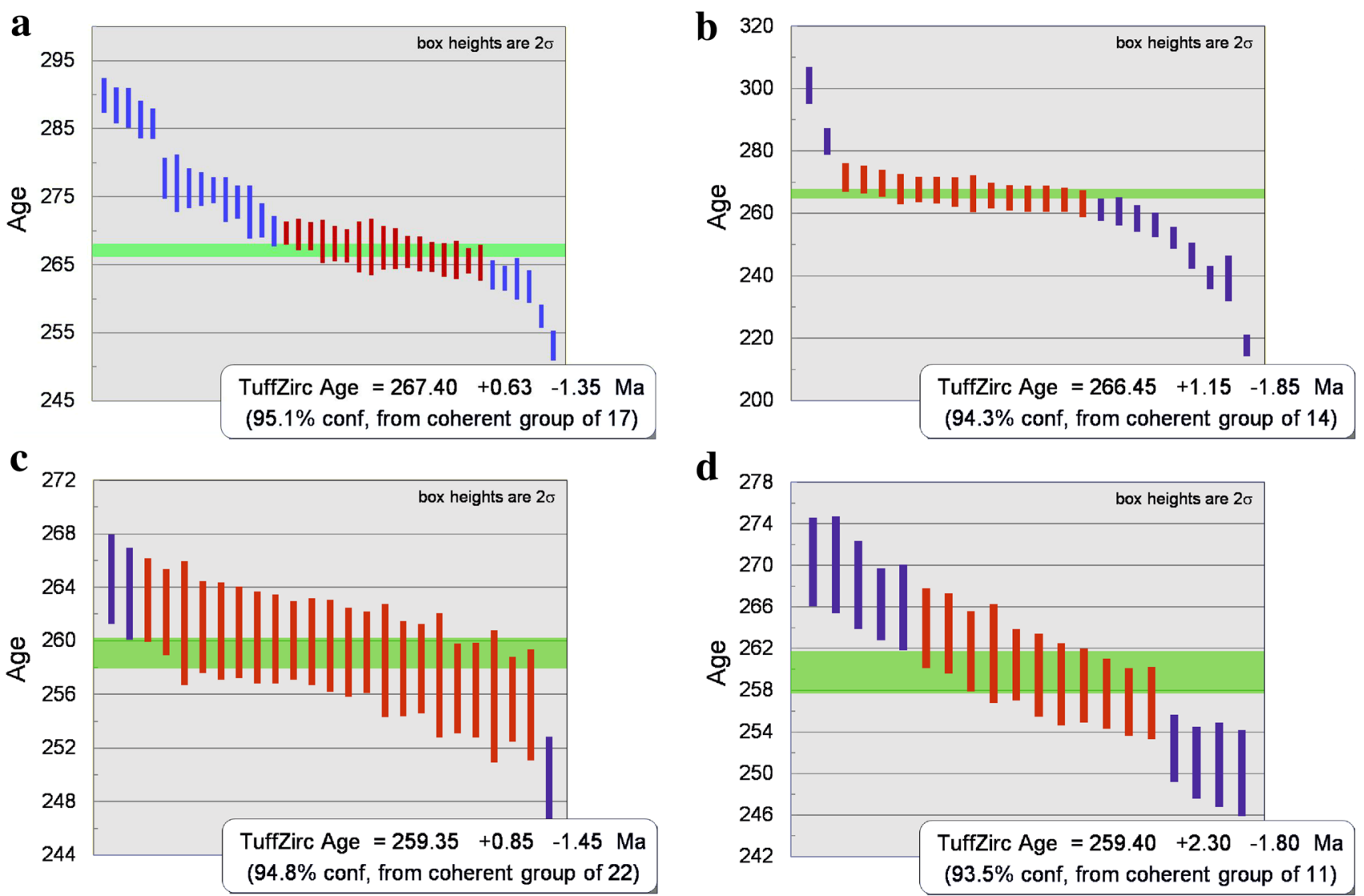

d
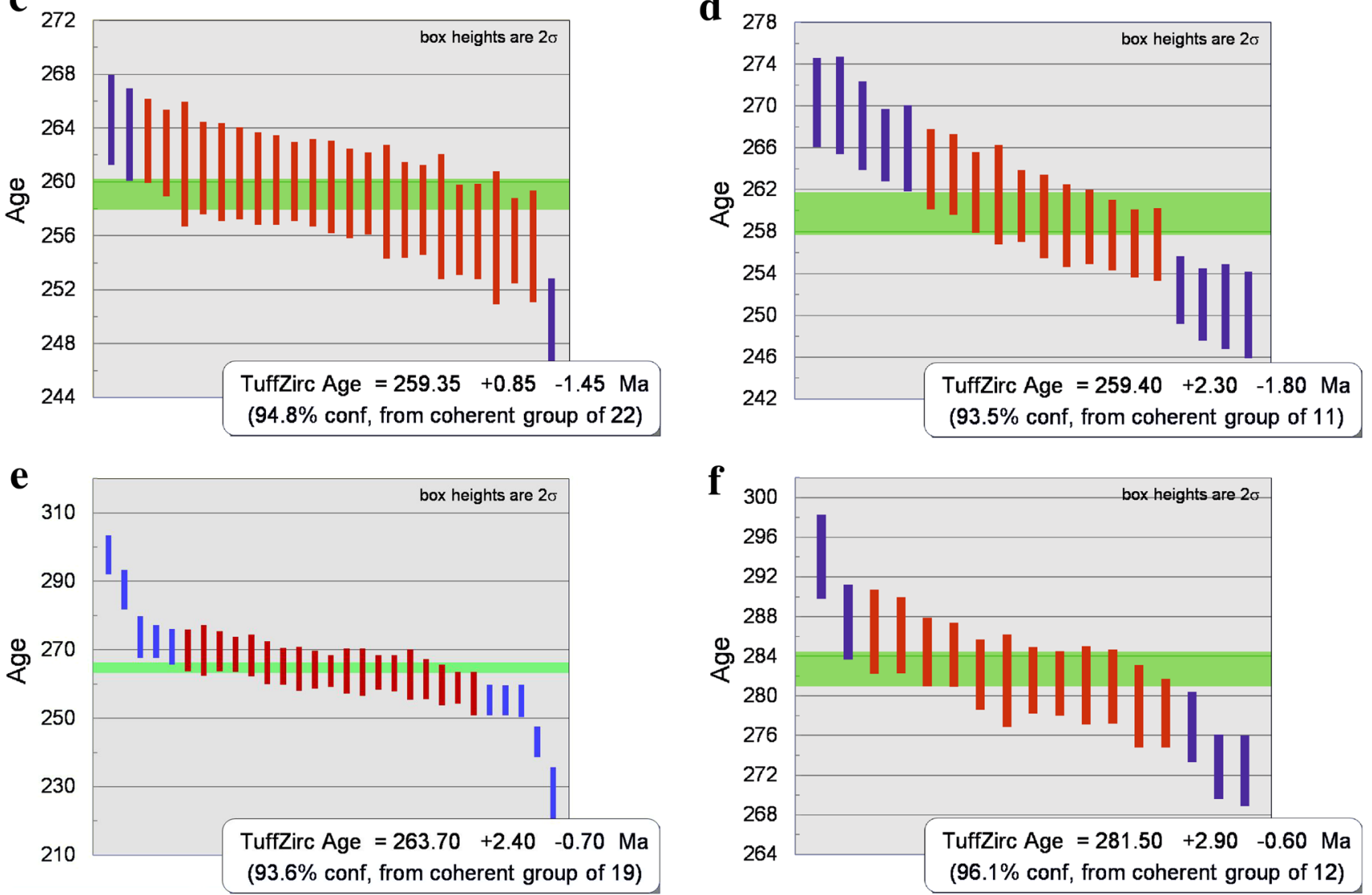

Fig. 6 Results of the zircon U-Pb geochronology of the Permian volcanic rocks. The TuffZirc algorithm (Ludwig 2002) was applied to identify the mean age of the youngest coherent age component. a Gy-1 sample (Western Mecsek Mts, outcrop), b Szava-1 sample

(northern foreland of the Villány Mts, borehole), c, d BATR/1 and BATR/2 samples (Battonya-Pusztaföldvár Basement Ridge, borehole), e Kelebia-7 sample (Kelebia area, borehole), f PR-1 sample (Polgárdi quarry, dyke)

In the $\mathrm{La}_{\mathrm{N}} / \mathrm{Yb}_{\mathrm{N}}$ vs. La $\mathrm{N}_{\mathrm{N}}$ diagram (Fig. 8c), samples of the SGU plot strikingly close to the trendline of the Permian felsic volcanic rocks of the Tisza MU. Closer genetic relationship cannot be excluded since the SGU (and other crustal-scale superunits of Westerns Carpathians, e.g., Northern and Southern Veporic Unit, Northern Gemeric Unit etc.) could have situated on the southern margin of the European plate during the Permian as well as the Tisza

MU (Haas et al. 1999). Notably, Permian volcanic rocks of Central Transdanubia show similar REE and trace-element patterns with the samples of the Northern Veporic Unit (Western Carpathians; Vozárová et al. 2016; Fig. 5) suggesting their relationship both being parts of the ALCAPA MU. 
Table 3 Petrographic classifications (based on the mineralogical, major element, and immobile trace element compositions) of the studied Permian volcanic rock samples from the Tisza Mega-unit and the ALCAPA Mega-unit

\begin{tabular}{|c|c|c|c|c|c|c|}
\hline \multirow{2}{*}{$\begin{array}{l}\text { Subsurface region } \\
\text { or outcrop }\end{array}$} & \multicolumn{5}{|c|}{ Tisza Mega-unit (Tisia Terrane) } & \multirow{2}{*}{$\begin{array}{l}\text { ALCAPA Mega- } \\
\text { unit } \\
\text { Central Trans- } \\
\text { danubia }\end{array}$} \\
\hline & $\begin{array}{l}\text { Western Mecsek } \\
\text { Mts }\end{array}$ & $\begin{array}{l}\text { Máriakéménd- } \\
\text { Báta Basement } \\
\text { Range }\end{array}$ & $\begin{array}{l}\text { Northern foreland } \\
\text { of the Villány Mts }\end{array}$ & $\begin{array}{l}\text { Battonya-Pusz- } \\
\text { taföldvár Base- } \\
\text { ment Ridge }\end{array}$ & Kelebia area & \\
\hline Lithology & $\begin{array}{l}\text { Pyroclastic rocks } \\
\text { (differently } \\
\text { welded ignim- } \\
\text { brites) }\end{array}$ & $\begin{array}{l}\text { Pyroclastic rocks } \\
\text { (welded ignim- } \\
\text { brites) }\end{array}$ & $\begin{array}{l}\text { Pyroclastic } \\
\text { rocks (Bisse- } \\
\text { 1, Peterd-1, } \\
\text { Vókány-2, } \\
\text { Egerág-7, } \\
\text { Szalánta-3) and } \\
\text { lavas (Bisse- } \\
\text { 1, Szava-1, } \\
\text { Egerág-7, Sza- } \\
\text { lánta-3) }\end{array}$ & $\begin{array}{l}\text { Pyroclastic rocks } \\
\text { (welded ignim- } \\
\text { brites) }\end{array}$ & $\begin{array}{l}\text { Pyroclastic rock } \\
\text { affected by } \\
\text { Alpine low-grade } \\
\text { metamophism }\end{array}$ & Lavas or dykes \\
\hline $\begin{array}{l}\text { Mineralogical clas- } \\
\text { sification }\end{array}$ & Rhyolite & Rhyolite & $\begin{array}{l}\text { Mostly rhyolites, } \\
\text { rhyodacite-dac- } \\
\text { ite (lavas of } \\
\text { Egerág-7 and } \\
\text { Szalánta-3) }\end{array}$ & Rhyolite & Rhyodacite & Dacite \\
\hline $\begin{array}{l}\text { Geochemical clas- } \\
\text { sification (TAS) }\end{array}$ & Rhyolite & Rhyolite & Rhyolite & Ryholite & Trachydacite & Dacite \\
\hline $\begin{array}{l}\text { Geochemical clas- } \\
\text { sification }(\mathrm{Zr} / \\
\left.\mathrm{TiO}_{2} \text { vs. } \mathrm{Nb} / \mathrm{Y}\right)\end{array}$ & Rhyodacite-dacite & Rhyodacite-dacite & Rhyodacite-dacite & $\begin{array}{l}\text { Rhyolite (subordi- } \\
\text { nate rhyodacite- } \\
\text { dacite) }\end{array}$ & Rhyodacite-dacite & Rhyodacite-dacite \\
\hline
\end{tabular}

\section{Geochronology and correlation}

Based on the results of the zircon U-Pb geochronology, the volcanic rocks of the Battonya-Pusztaföldvár BR give slightly younger formation age ( $260 \mathrm{Ma})$ than those found in Southern Transdanubia and the Kelebia area (267-264 Ma) of the Tisza MU. The ALCAPA sample (Polgárdi) gives the oldest age ( 281 Ma) and it is closer to the 291 Ma ID-TIMS age of the Kékkút-4 sample (Lelkes-Felvári and Klötzli 2004). The apparent age difference between Kékkút-4 and Polgárdi samples may be explained by older cores in the bulk zircon age determination supported by the fact that two older single crystal ages were ruled out of the six analyses by Lelkes-Felvári and Klötzli (2004) in the interpretation of the U-Pb ages in the Kékkút-4 sample, suggesting the presence of inherited cores in the zircon crystals. The presence of old cores could indicate crustal components in their petrogenesis.

There is a striking similarity in the ages with the Permian rhyolites from the Silicic Unit (Western Carpathians; Ondrejka et al. 2018; Fig. 9). Permian volcanic rocks of the Northern Veporic Unit and the Gemeric Unit (Figs. 9, $10 \mathrm{~b})$ have slightly older zircon ages that are more closer the age of the Polgárdi sample ( 281 Ma) of the ALCAPA MU, supporting the geochemical correlation between the Permian felsic volcanic rocks of the Northern Veporic Unit and Central Transdanubia (Fig. 5). Lelkes-Felvári and Klötzli (2004) suggested a possible genetic link between the Kékkút-4 sample and the Bozen/Bolzano Quartz Porphyry from the Southern Alps located in the same mega-unit (e.g., Morelli et al. 2007).

In the Western Carpathians a dominant Kungurian magmatic event ( 280-270 Ma; Fig. 9) was documented and linked to post-orogenic transpression/transtension tectonic movements (Vozárová et al. 2009, 2015, 2016). However, significantly younger volcanic episodes (up to the Permian-Triassic boundary, $251 \mathrm{Ma}$ ) are also known in the area that were linked to an extensional tectonic setting (continental rift; Vozárová et al. 2015; Ondrejka et al. 2018). As it was mentioned before, most of the observed samples fall into the border between the volcanic-arc and the within-plategranite fields (Fig. 8a); however, the youngest volcanic rocks (Battonya-Pusztaföldvár BR and Kelebia area; Fig. 9) plot clearly in the within-plate-granite field. Thereby, these rocks could be connected to the beginning of the Alpine orogenic cycle, the extensional setting succeeding the post-collisional environment in which the volcanic rocks of Transdanubia (samples of the ALCAPA MU and Southern Transdanubia) could be formed.

Pană et al. (2002) published two U-Pb ID-TIMS zircon ages $(266.7 \pm 3.8 \mathrm{Ma}$ and $264.2 \pm 2.3 \mathrm{Ma})$, which actually cannot be distinguished, for two different rock types from the 

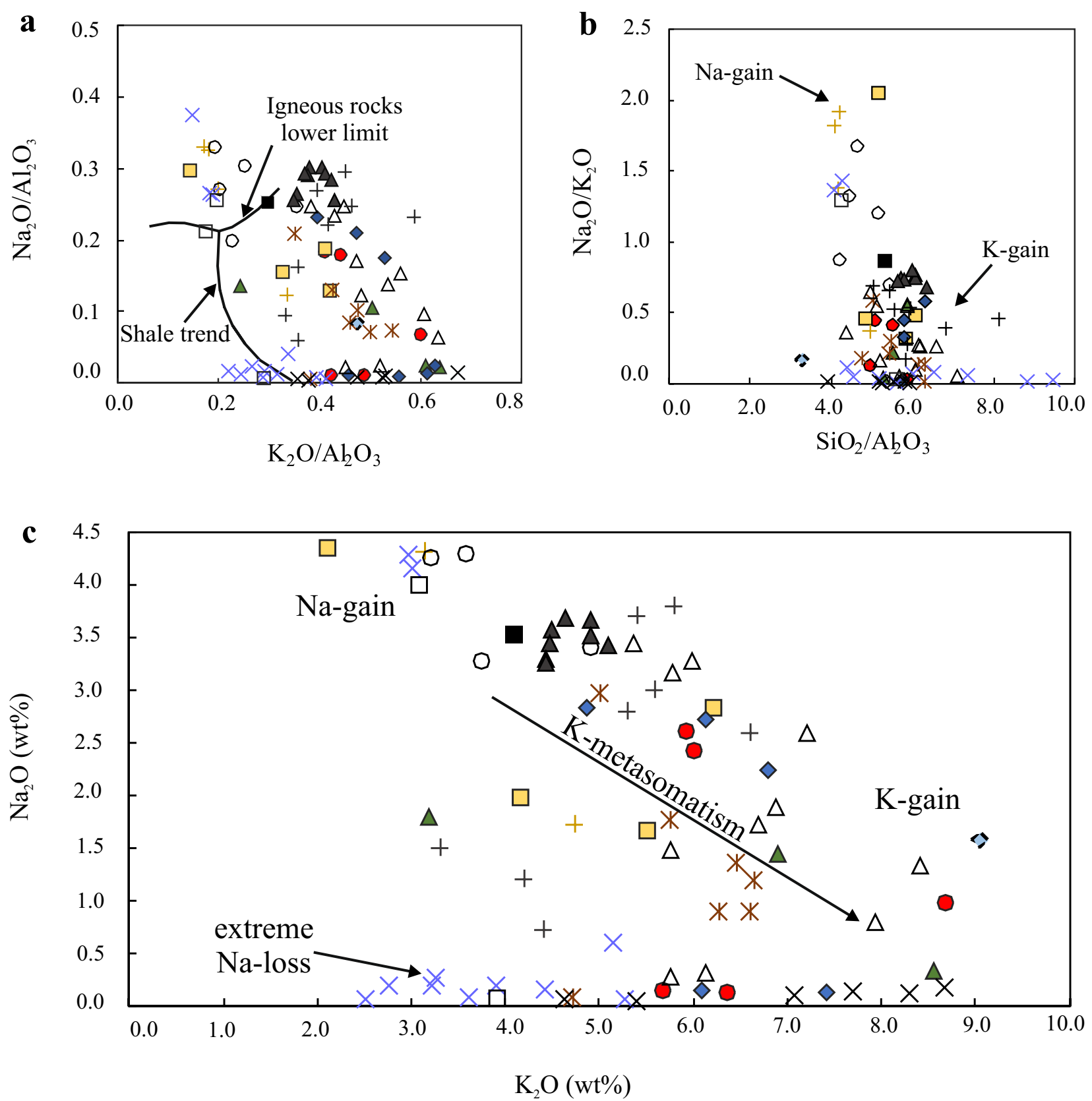

\begin{tabular}{|c|c|c|c|c|}
\hline & Tisza Mega-unit (HU) & - & $\begin{array}{c}\text { ALCAPA Mega-unit } \\
\text { (Central Transdanubia, HU) }\end{array}$ & $\triangle$ Intra-Sudetic Basin $(\mathrm{PL})$, younger \\
\hline$\square$ & Western Mecsek Mts & Y & Anuseni Mts (RO) Tisza Meoa-un & Intra-Sudetic Basin (PL), older \\
\hline$\angle$ & Máriakéménd-Báta BR & 木 & 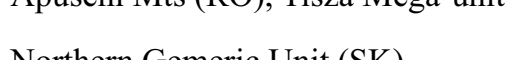 & + Northeast Germany (D) \\
\hline & Northern foreland of the Villány Mts & $x$ & Northern Gemeric Unit (SK) & Highiş massif (RO), granites \\
\hline & Battonya-Pusztaföldvár BR & $x$ & Southern Gemeric Unit (SK) & \\
\hline ハ & Kelebia area & + & Northern Veporic Unit (SK) & \\
\hline
\end{tabular}

Fig. $7 \mathrm{Na}_{2} \mathrm{O} / \mathrm{Al}_{2} \mathrm{O}_{3}$ vs. $\mathrm{K}_{2} \mathrm{O} / \mathrm{Al}_{2} \mathrm{O}_{3}(\mathbf{a}), \mathrm{Na}_{2} \mathrm{O} / \mathrm{K}_{2} \mathrm{O}$ vs. $\mathrm{SiO}_{2} / \mathrm{Al}_{2} \mathrm{O}_{3}(\mathbf{b}$; Garrels and Mackenzie 1971) and $\mathrm{Na}_{2} \mathrm{O}$ vs. $\mathrm{K}_{2} \mathrm{O}$ diagrams (c; Paulick and Breitkreuz 2005) focusing on the post-magmatic alterations of Permian volcanic rocks of the Tisza Mega-unit, the ALCAPA Mega- unit, Hungary and the analogous formations from the European Variscides. The references of the comparative data are the same as those in Fig. 3 

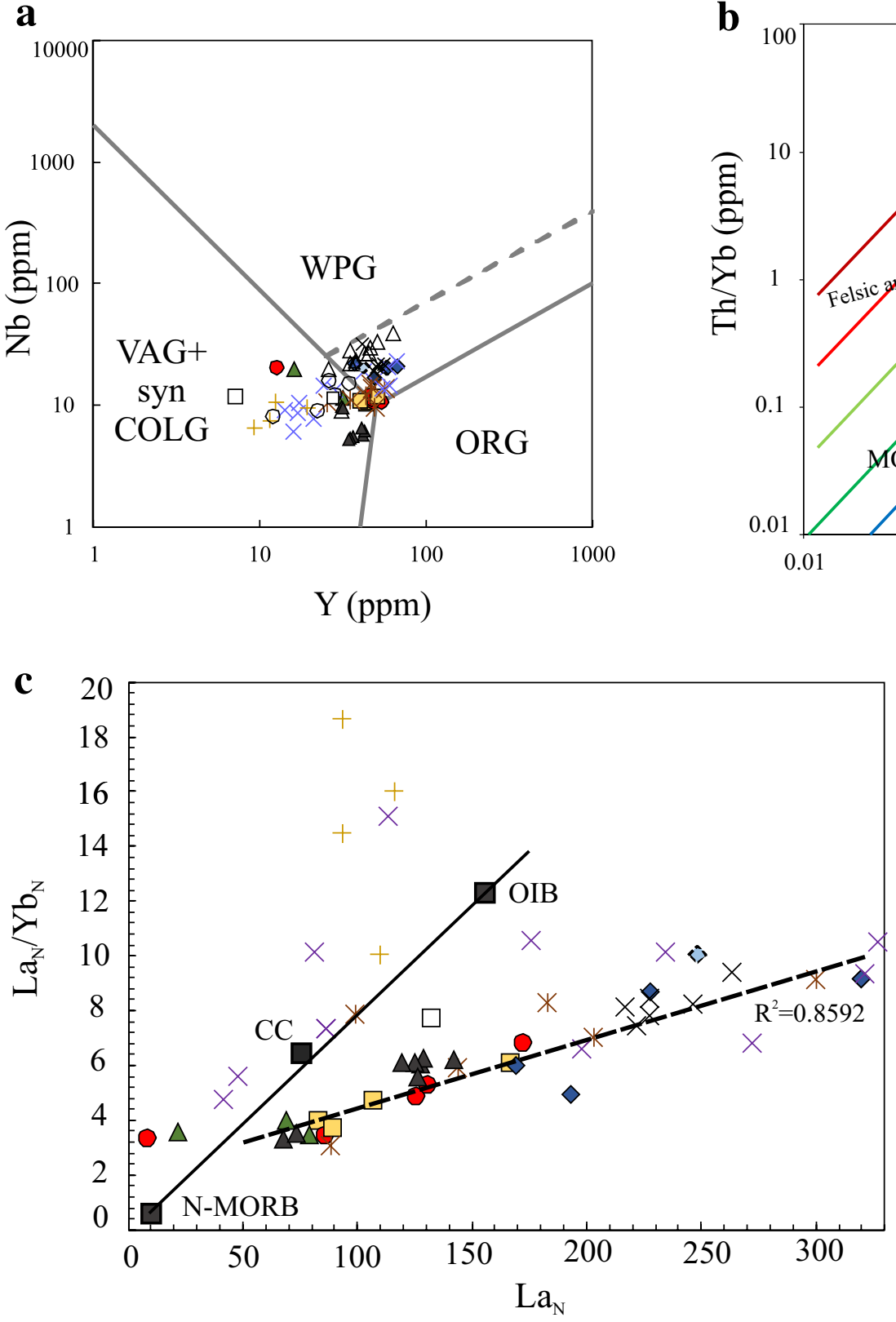

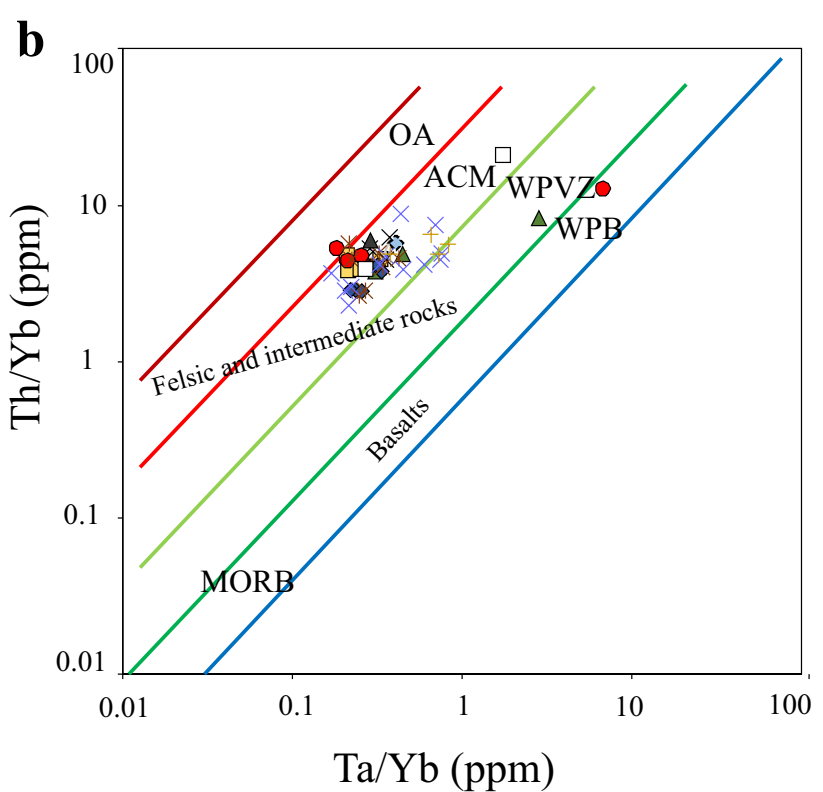

Fig. 8 Nb-Y (a; Pearce et al. 1984) and Th/Yb vs. Ta/Yb (b; Gorton and Schandl 2000) discrimination diagrams and $\mathrm{La}_{\mathrm{N}} \mathrm{vs}$. $\mathrm{La}_{\mathrm{N}} / \mathrm{Yb}_{\mathrm{N}}$ diagram (c) for the Permian volcanic rocks of the Tisza Mega-unit, the ALCAPA Mega-unit, Hungary and the analogous formations of the European Variscides. ORG ocean ridge granites, syn-COLG syncollision granites, VAG volcanic-arc granites, WPG within-plate gran-

anorogenic Highiş massif (Apuseni Mountains, Romania; Fig. 10). These ages agree with the age data of the Permian volcanic rocks of the Tisza MU corroborating the geochemical observations and the assumption about their genetic link. ites, $O A$ oceanic arcs, $A C M$ active continental margins, $W P V Z$ withinplate volcanic zones, $W P B$ within-plate basalts, $M O R B$ mid-ocean ridge basalts, $N-M O R B$ Mid-Ocean Ridge Basalt (Sun and McDonough 1989), OIB Ocean Island Basalt (Sun and McDonough 1989), $C C$ average continental crust (Rudnick and Fountain 1995). The references of the comparative data are the same as those in Fig. 3

Regarding a broader correlation, the radiometric ages of the studied Permian volcanic rocks of the Tisza MU are significantly younger than the zircon ages of other well studied parts of the Central European Variscides (e.g., Intra-Sudetic Basin, NE Germany), where much older ages were detected 


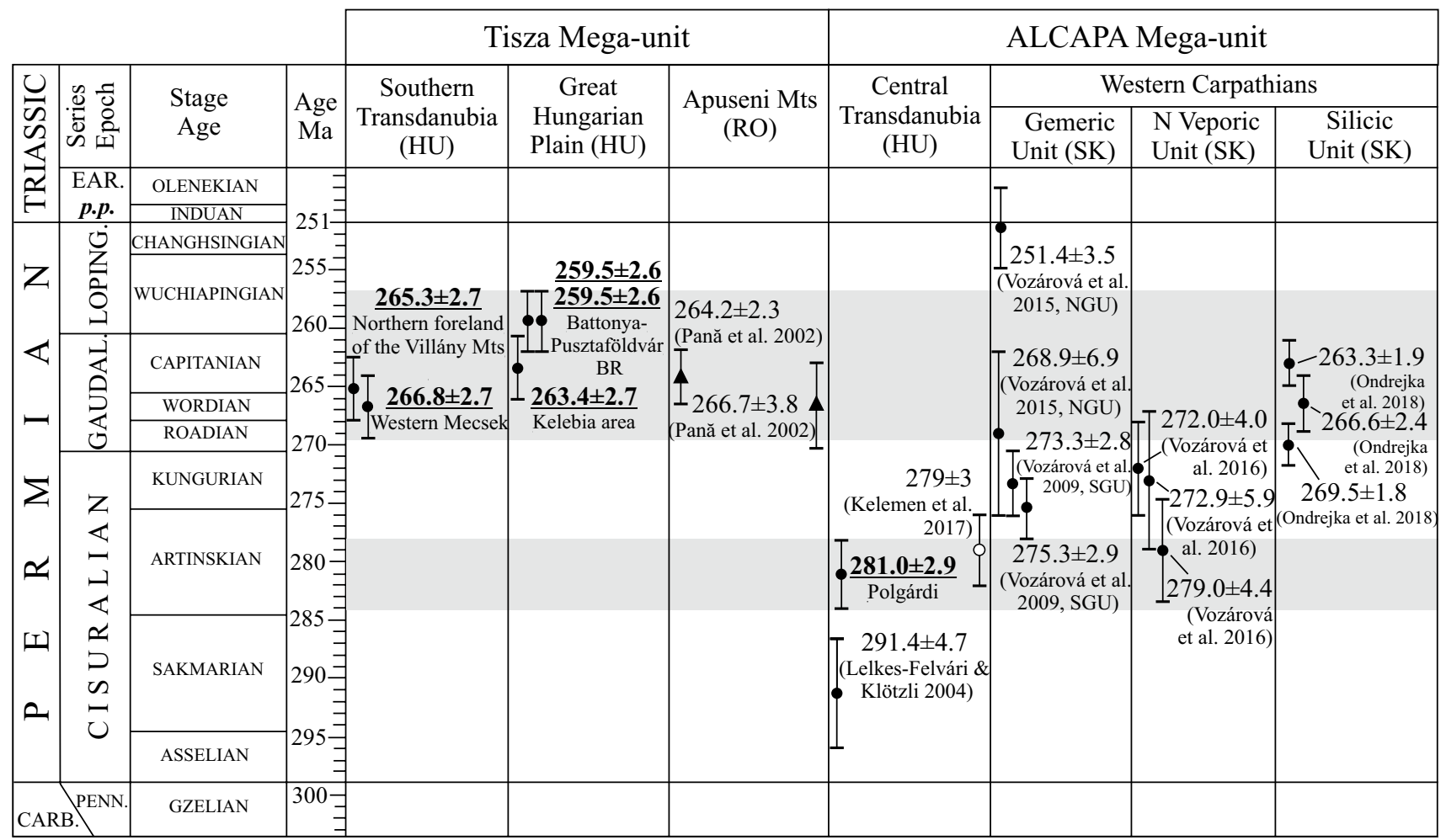

Fig. 9 Radiometric age data of Permian felsic volcanic rocks of the European Variscides, summarizing all magmatic events that are significant for the correlation of the Permian felsic volcanic rocks in Hungary (Pană et al. 2002; Lelkes-Felvári and Klötzli 2004; Vozárová et al. 2009, 2015, 2016; Kelemen et al. 2017; Ondrejka

( 300-280 Ma; Breitkreuz and Kennedy 1999; Wilson et al. 2004; Awdankiewicz and Kryza 2010; Repstock et al. 2017; Słodczyk et al. 2018).

\section{Conclusions}

Permo-Carboniferous volcanism controlled by a post-collisional to extensional tectonic setting is a common feature in the European Variscan Orogenic Belt. In the territory of Hungary, two distinct Permian volcanic activities were revealed by $\mathrm{U}-\mathrm{Pb}$ zircon geochronology: an older one ( $281 \mathrm{Ma}$, Cisuralian) resulting in dacitic lava flows/domes and dykes in the ALCAPA MU, and a younger volcanic activity ( 267-260 Ma, Gaudalupian) producing rhyodacitic/dacitic to rhyolitic pyroclastic and subordinate lavas in the Tisza MU. Most of these Permian volcanic rocks are affected by various post-magmatic processes (K-metasomatism, albitization, Alpine low-grade metamorphism, hydrothermal alteration), which variably modified their major et al. 2018). The U-Pb zircon age of this study are bold and underlined. Carb. Carboniferous, Ear. Early Triassic, Guadal. Guadalopian, Loping. Lopingian, Penn. Pennsylvanian, HU Hungary, RO Romania, SK Slovakia

element composition. However, in most cases, the immobile, incompatible trace elements provide valuable information about the rock types and the petrogenetic processes.

Permian volcanic rocks are less abundant in Central Transdanubia (ALCAPA MU), where dacitic lavas are known by boreholes and as dykes in the limestone quarry near Polgárdi. These rocks are less affected by post-magamatic alterations preserving their original major element composition. Based on trace element geochemistry and zircon geochronology, the dacitic lavas of Central Transdanubia correlate with the volcanic rocks from the Northern Veporic Unit (Slovakia) that is located also in the ALCAPA MU.

In the Tisza MU, crystal-rich rhyodacitic/dacitic ignimbrites are the dominant lithologies (Southern Transdanubia and the Kelebia area), while crystal-poor rhyolitic ignimbrites (Battonya-Pusztaföldvár BR) are less common. In this tectonic unit, lavas are subordinate, rhyodacitic/dacitic lavas occur in the northern foreland of the Villány Mts (Southern Transdanubia). Permian felsic volcanic rocks within the 


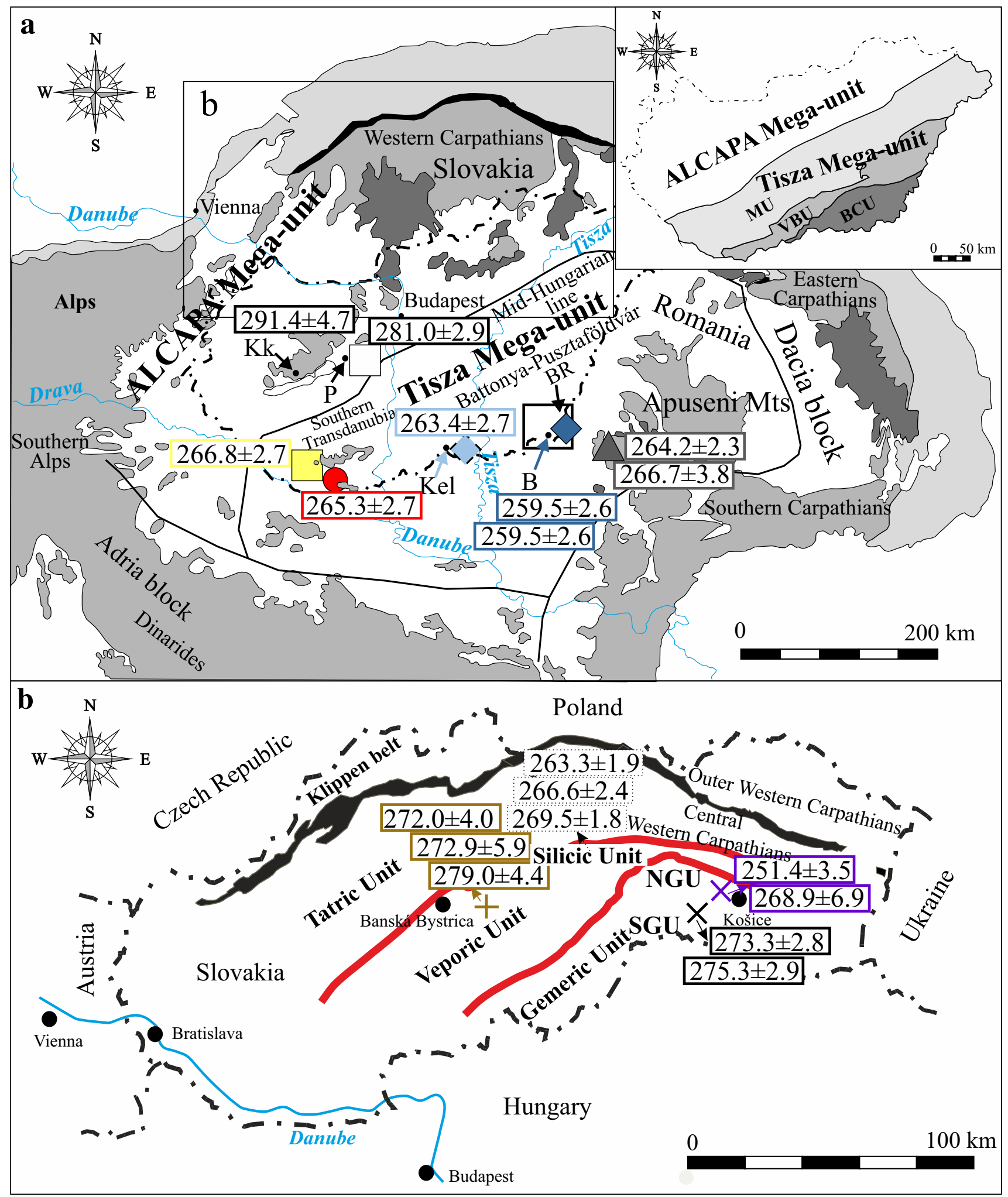

Fig. 10 Permian felsic magmatic events in the Carpathian-Pannonian region (a) displayed by weighted mean ages (Ma), highlighting crustal-scale superunits of the Western Carpathians and representative ages (b, modified after Kohút et al. 2013). Index map shows the Alpine facies zones of the study area (modified after Szederké- nyi et al. 2013). $M U$ Mecsek Unit, $V B U$ Villány-Bihor Unit, $B C U$ Békés-Codru Unit, $N G U$ Northern Gemeric Unit, $S G U$ Southern Gemeric Unit. Results derive from Pană et al. (2002), Lelkes-Felvári and Klötzli (2004), Vozárová et al. (2009, 2015, 2016), Ondrejka et al. (2018) 
Tisza MU could represent the same volcanic activity and can be correlated with the felsic rocks found in the Apuseni Mts (Romania). Moreover, these volcanic rocks show potential relationship with Permian granitic rocks of the Highiş massif, Apuseni Mts (according to their geochemical character and zircon $\mathrm{U}-\mathrm{Pb}$ ages).

Based on the new geochronological results Permian volcanic rocks not only in Central Transdanubia, but also in the Tisza MU show similarity with such rocks of the Western Carpathians (ALCAPA MU).

Acknowledgements Open access funding was provided by University of Szeged (SZTE). Geochronological and correlation studies were supported by the Bolyai Research Scholarship of the Hungarian Academy of Sciences to Réka Lukács (No. BO/114/14) and Andrea Varga (No. $\mathrm{BO} / 266 / 18$ ). Regional correlation studies were supported by the New National Excellence Program of the Ministry of Human Capacities (Hungary) to Andrea Varga (Nos. UNKP-17-4, UNKP-18-4-SZTE-16) and Máté Szemerédi (No. UNKP-18-3-I-SZTE-90). Additionally, some parts of this research were financed by the Hungarian Scientific Research Fund projects PD 83511, PD 121048, and K 108375 (Hungary) and also supported by the European Union and the State of Hungary, co-financed by the European Regional Development Fund in the project of GINOP-2.3.2-15-2016-00009 'ICER'. We are greatful to Ioan Seghedi (Institute of Geodynamics, Romanian Academy) for his constructive suggestions in the manuscript and to Gyöngyi LelkesFelvári for providing samples from the Kékkút-4 borehole (Central Transdanubia, ALCAPA Mega-unit). We would like to thank Dr. Albrecht von Quadt and the anonymous referee for their suggestions and constructive comments that improve our manuscript, as well as Associated Editor Dr. Axel Gerdes for the editorial work.

Open Access This article is distributed under the terms of the Creative Commons Attribution 4.0 International License (http://creativeco mmons.org/licenses/by/4.0/), which permits unrestricted use, distribution, and reproduction in any medium, provided you give appropriate credit to the original author(s) and the source, provide a link to the Creative Commons license, and indicate if changes were made.

\section{References}

Awdankiewicz M (1999) Volcanism in a late Variscan intramontane trough: the petrology and geochemistry of the Carboniferous and Permian volcanic rocks of the Intra-Sudetic Basin, SW Poland. Geol Sudetica 32:81-111

Awdankiewicz M, Kryza R (2010) The Góry Suche Rhyolitic Tuffs (Intra-Sudetic Basin, SW Poland): preliminary SHRIMP zircon age. Mineral Spec Pap 37:19

Bachmann O, Bergantz GW (2008) Rhyolites and their source mushes across tectonic settings. J Petrol 49(12):2277-2285. https://doi. org/10.1093/petrology/egn068

Balogh K, Kovách Á (1973) Determination of the Battonya quartz porphyries age by Rb/Sr method. ATOMKI Közl 15(4):245-249 (in Hungarian with English abstract)

Barabásné Stuhl Á (1988) A Dél-Baranyai dombság és a Villányi hegység permi képződményeinek kutatásáról készített összefoglaló jelentés IV. fejezete a permi képződményekrôl. Mecsekérc Ltd. (former Mecsek Ore Mining Company), pp 100-213 (in Hungarian)

Black LP, Kamo SL, Allen CM, Davis DW, Aleinikoff JN, Valley JW, Mundil R, Campbell IH, Korsch RJ, Williams IS, Foudoulis C
(2004) Improved ${ }^{206} \mathrm{~Pb} /{ }^{238} \mathrm{U}$ microprobe geochronology by the monitoring of a trace-element-related matrix effect; SHRIMP, ID-TIMS, ELA-ICP-MS and oxygen isotope documentation for a series of zircon standards. Chem Geol 205(1):115-140. https:// doi.org/10.1016/j.chemgeo.2004.01.003

Breitkreuz C (2013) Spherulites and lithophysae-200 years of investigation on high-temperature crystallization domains in silica-rich volcanic rocks. Bull Volcanol 75:705. https://doi.org/10.1007/ s00445-013-0705-6

Breitkreuz C, Kennedy A (1999) Magmatic flare-up at the Carboniferous/Permian boundary in the NE German Basin revealed by SHRIMP zircon ages. Tectonophysics 302:307-326. https://doi. org/10.1016/s0040-1951(98)00293-5

Christiansen EH (2005) Contrasting processes in silicic magma chambers: evidence from very large volume ignimbrites. Geol Mag 142:669-681. https://doi.org/10.1017/s0016756805001445

Christiansen EH, McCurry M (2008) Contrasting origins of Cenozoic silicic rocks from the western Cordillera of the United States. Bull Volcanol 70(3):251-267. https://doi.org/10.1007/s0044 5-007-0138-1

Condie KC (1993) Chemical composition and evolution of the upper continental crust: contrasting results from surface samples and shales. Chem Geol 104:1-37. https://doi.org/10.1016/00092541(93)90140-e

Cortesogno L, Cassinis G, Dallagiovanna G, Gaggero L, Oggiano G, Ronchi A, Seno S, Vanossi M (1998) The post-Variscan volcanism in the Late Carboniferous-Permian sequences of Ligurian Alps, Southern Alps and Sardinia. Lithos 45:305-328. https:// doi.org/10.1016/s0024-4937(98)00037-1

Császár G (2005) Magyarország és környezetének regionális földtana, I. Paleozoikum-paleogén. Eötvös University Press, Budapest (in Hungarian)

Dostal J, Vozár J, Keppie JD, Hovorka D (2003) Permian volcanism in the Central Western Carpathians (Slovakia): basin-and-Range type rifting in the southern Laurussian margin. Int J Earth Sci 92:27-35

Dunkl I, Mikes T, Simon K, von Eynatten H (2008) Brief introduction to the Windows program Pepita: data visualization, and reduction, outlier rejection, calculation of trace element ratios and concentrations from LA-ICP-MS data. In: Sylvester P (ed) Laser ablation ICP-MS in the earth sciences: current practices and outstanding issues. Mineralogical Association of Canada, pp 334-340

Fazekas V (1978) Kutatási Zárójelentés: A magyarországi felsőpaleozoos vulkanitok ásvány-kőzettani-, kémiai-, valamint sugárzóanyag-tartalom vizsgálata. Closing report, Mecsek Ore Mining Company (J-3033) (in Hungarian)

Fazekas V, Vincze J (1991) Hidrotermás ércindikációk a Villányi-hegység északi előtere mélyfúrásaiban. Földtani Közlöny 121:23-56 (in Hungarian)

Frei D, Gerdes A (2009) Precise and accurate in situ U-Pb dating of zircon with high sample throughput by automated LA-SF-ICPMS. Chem Geol 261(3-4):261-270. https://doi.org/10.1016/j. chemgeo.2008.07.025

Fülöp J (1990) Magyarország geológiája, Paleozoikum I. (Geology of Hungary, Paleozoic I). Akadémiai Kiadó, Budapest (in Hungarian)

Fülöp J (1994) Magyarország geológiája, Paleozoikum II (Geology of Hungary, Paleozoic II). Akadémiai Kiadó, Budapest (in Hungarian)

Garrels RM, Mackenzie FT (1971) Evolution of sedimentary rocks. Norton, New York

Gifkins CC, Allen RL, McPhie J (2005) Apparent welded textures in altered pumice-rich rocks. J Volcanol Geotherm Res 142:29-47. https://doi.org/10.1016/j.jvolgeores.2004.10.012 
Gorton MP, Schandl ES (2000) From continents to island arcs: a geochemical index of tectonic setting for arc-related and within-plate felsic to intermediate volcanic rocks. Can Mineral 38:1065-1073. https://doi.org/10.2113/gscanmin.38.5.1065

Haas J, Hámor G, Korpás L (1999) Geological setting and tectonic evolution of Hungary. Geol Hungar Ser Geol 24:179-196

Haas J, Tait J, Körner F (2008) Permian. In: McCann T (ed) The geology of Central Europe, V1: Precambrian and Paleozoic. Geological Society, London, pp 531-597

Harangi SZ, Downes H, Kósa L, Szabó CS, Thirlwall MF, Mason PRD, Mattey D (2001) Almandine garnet in calc-alkaline volcanic rocks of the northern Pannonian Basin (Eastern-Central Europe): geochemistry, petrogenesis and geodynamic implications. J Petrol 42(10):1813-1843. https://doi.org/10.1093/petrology/42.10.1813

Hidasi T, Varga A, Pál-Molnár E (2015) Petrographic analysis of Gyúrüfú Rhyolite Formation using the thin section collection of Mecsek Ore Company. Földtani Közlöny 145(1):3-22 (in Hungarian with English abstract)

Hildreth W (1981) Gradients in silicic magma chambers: implications for lithospheric magmatism. J Geophys Res Sol EA 86:1015310192. https://doi.org/10.1002/9781118782057.ch3

Horstwood MSA, Košler J, Gehrels G, Jackson SE, McLean NM, Paton C, Pearson NJ, Sircombe K, Sylvester P, Vermeesch P, Bowring JF, Condon DJ, Schoene B (2016) Community-derived standards for LA-ICP-MS U-(Th)-Pb geochronology-uncertainity propagation, age interpretation and data reporting. Geostand Geoanal Res 40:311-332. https://doi.org/10.1111/j.1751-908x.2016.00379 . $\mathrm{x}$

Huber C, Bachmann O, Dufek S (2012) Crystal-poor versus crystalrich ignimbrites: a competition between strirring and reactivation. Geology 40:115-118. https://doi.org/10.1130/g32425.1

Hughes CJ (1972-1973) Spilites, keratophyres, and the igneous spectrum. Geol Mag 109(6):513-527. https://doi.org/10.1017/s0016 756800042795

Jackson SE, Pearson NJ, Griffin WL, Belousova EA (2004) The application of laser ablation-inductively coupled plasma-mass spectrometry to in situ U-Pb zircon geochronology. Chem Geol 211:47-69. https://doi.org/10.1016/j.chemgeo.2004.06.017

Jiang SY, Wang RC, Xu XS, Zhao KD (2004) Mobility of high field strength elements (HFSE) in magmatic-, metamorphic-, and submarine-hydrothermal systems. Phys Chem Earth 30:1020-1029. https://doi.org/10.1016/j.pce.2004.11.004

Kelemen P, Dunkl I, Csillag G, Mindszenty A, von Eynatten H, Józsa S (2017) Tracing multiple resedimentation on an isolated karstified plateau: the bauxite-bearing Miocene red clay of the Southern Bakony Mountains, Hungary. Sediment Geol 358:84-96. https:// doi.org/10.1016/j.sedgeo.2017.07.005

Kohút M, Trubač J, Novotný L, Ackerman L, Demko R, Bartalský B, Erban V (2013) Geology and Re-Os molybdenite geochronology of the Kurišková U-Mo deposit (Western Carphatians, Slovakia). J Geosci 58:275-286. https://doi.org/10.3190/jgeosci.150

Konrád GY, Földing G, Barabás A, Unyi P (2012) Geology, experimental in situ leaching and site remediation of the Dinnyeberki uranium ore deposit. Földtani Közlöny 142(4):357-374 (in Hungarian with English abstract)

Le Maitre RW, Streckeisen A, Zanettin B, Le Bas MJ, Bonin B, Bateman P (1989) Igneous rocks: a classification and glossary of terms. Recommendations of the International Union of Geological Sciences Subcommission on the Systematics of Igneous Rocks. Blackwell, Oxford

Lelkes-Felvári GY, Klötzli U (2004) Zircon geochronology of the "Kékkút quartz porphyry", Balaton Highland, Transdanubian Central Range, Hungary. Acta Geol Hungar 47(2-3):139-149. https://doi.org/10.1556/ageol.47.2004.2-3.4

Letsch D, Winkler W, von Quadt A, Gallhofer D (2014) The volcanosedimentary evolution of a post-Variscan intramontane basin in the Swiss Alps (Glarus Verrucano) as revealed by zircon $\mathrm{U}-\mathrm{Pb}$ age dating and $\mathrm{Hf}$ isotope geochemistry. Int J Earth Sci 104:123145. https://doi.org/10.1007/s00531-014-1055-0

Ludwig KR (2002) User's manual for Isoplot 3.75: a geochronological Toolkit for Microsoft Excel. Berkeley Geochronology Center Special Publication No. 4

Mattinson JM (2005) Zircon U-Pb chemical abrasion ("CA-TIMS") method: combined annealing and multi-step partial dissolution analysis for improved precision and accuracy of zircon ages. Chem Geol 220(1):47-66. https://doi.org/10.1016/j.chemg eo.2005.03.011

Morelli C, Bargossi GM, Mair V, Marocchi M, Moretti A (2007) The lower Permian volcanics along the Etsch Valley from Meran to Auer (Bozen). Mitt Oesterr Mineral Ges 153:129-152

Nicolae I, Seghedi I, Boboş I, Azevedo MR, Ribeiro S, Tatu M (2014) Permian volcanic rocks from the Apuseni Mountains (Romania): geochemistry and tectonic constrains. Chem Erde-Geochem 74:125-137. https://doi.org/10.1016/j.chemer.2013.03.002

Ondrejka M, Li XH, Vojtko R, Putiš M, Uher P, Sobocký T (2018) Permian A-type rhyolites of the Muraň Nappe, Inner Western Carpathians, Slovakia: in situ zircon U-Pb SIMS ages and tectonic setting. Geol Carpath 69(2):187-198. https://doi.org/10.1515/ geoca-2018-0011

Pál-Molnár E, András E, Zs Kassay, Gy Buda, Batki A (2008) Petrology of Păuliş Granites (Apuseni Mts., Romania). Acta Mineral Petrogr 48:33-41

Pană DI, Heaman LM, Creaser RA, Erdmer P (2002) Pre-alpine crust in the Apuseni Mountains, Romania: insights from $\mathrm{Sm}-\mathrm{Nd}$ and U-Pb data. J Geol 110:341-354. https://doi.org/10.1086/339536

Paton C, Woodhead JD, Hellstrom JC, Hergt JM, Greig A, Maas $\mathrm{R}$ (2010) Improved laser ablation U-Pb zircon geochronology through robust downhole fractionation correction. Geochem Geophys. https://doi.org/10.1029/2009gc002618

Paton C, Hellstrom J, Paul B, Woodhead J, Hergt J (2011) Iolite: freeware for the visualisation and processing of mass spectrometric data. J Anal Atom Spectrom 26(12):2508-2518. https:// doi.org/10.1039/c1ja10172b

Paulick H, Breitkreuz C (2005) The Late Paleozoic felsic lava-dominated large igneous province in northeast Germany: volcanic facies analysis based on drill cores. Int J Earth Sci 94:834-850. https://doi.org/10.1007/s00531-005-0017-y

Pearce JA, Harris NBW, Tindle AG (1984) Trace element discrimination diagrams for the tectonic interpretation of granitic rocks. J Petrol 24(4):956-983. https://doi.org/10.1093/petro $\log / 25.4 .956$

Petrus JA, Kamber BS (2012) VizualAge: a novel approach to laser ablation ICP-MS U-Pb geochronology data reduction. Geostand Geoanal Res 36(3):247-270. https://doi.org/10.1111/j.1751908x.2012.00158.x

Raucsik B, Varga A, Mészáros E, Szemerédi M (2016) Very low-grade metamorphism of the Cisuralian basement formations (Korpád Sandstone, Gyúrúfú Rhyolite) near Kelebia, Békés Unit, Hungary. Conference abstract, 8th Mid-European Clay Conference, Košice

René M (2014) Rare-earth, yttrium and zirconium mobility associated with the uranium mineralisation at Okrouhlá Radouň, Bohemian Massif, Czech Republic. Eur J Mineral 27:57-70. https://doi. org/10.1127/ejm/2015/0027-2422

Repstock A, Breitkreuz C, Lapp M, Schulz B (2017) Voluminous and crystal-rich igneous rocks of the Permian Wurzen volcanic system, northern Saxony, Germany: physical volcanology and geochemical characterization. Int J Earth Sci 107:1485-1513. https ://doi.org/10.1007/s00531-017-1554-x

Rubin JN, Henry CD, Price JG (1993) The mobility of zirconium and other "immobile" elements during hydrothermal alteration. Chem Geol 110:29-47. https://doi.org/10.1016/0009-2541(93)90246-f 
Rudnick RL, Fountain DM (1995) Nature and composition of the continental crust-a lower crustal perspective. Rev Geophys 33:267309. https://doi.org/10.1029/95rg01302

Seghedi I (2010) Permian rhyolitic volcanism, changing from subaqueous to subaerial in post-Variscan intra-continental Sirinia Basin (SW Romania-Eastern Europe). J Volcanol Geotherm Res 201:312-324. https://doi.org/10.1016/j.jvolgeores.2010.07.015

Sláma J, Košler J, Condon DJ, Crowley JL, Gerdes A, Hanchar JM, Horstwood MSA, Morris GA, Nasdala L, Norberg N, Schaltegger U, Schoene B, Tubrett MN, Whitehouse MJ (2008) Plešovice zircon-a new natural reference material for $\mathrm{U}-\mathrm{Pb}$ dating and $\mathrm{Hf}$ isotopic microanalyses. Chem Geol 249(1-2):1-35. https://doi. org/10.1016/j.chemgeo.2007.11.005

Sliwinski J, Guillong M, Liebske Ch, Dunkl I, von Quadt A, Bachmann O (2017) Improved accuracy of LA-ICP-MS U-Pb ages in Cenozoic zircons by alpha dose correction. Chem Geol 472:8-21. https ://doi.org/10.1016/j.chemgeo.2017.09.014

Słodczyk E, Pietranik A, Glynn S, Wiedenbeck M, Breitkreuz C, Dhuime B (2018) Contrasting sources of Late Paleozoic rhyolite magma in the Polish Lowlands: evidence from $\mathrm{U}-\mathrm{Pb}$ age and $\mathrm{Hf}$ and $\mathrm{O}$ isotope composition in zircon. Int J Earth Sci 107:2065. https://doi.org/10.1007/s00531-018-1588-8

Sun SS, McDonough WF (1989) Chemical and isotopic systematic of oceanic basalts implications for mantle compositions and processes. In: Saunders AD, Norry MJ (eds) Magmatism in ocean basins, 42. Geological Society London Special Publication, London, pp 312-345

Szederkényi T (1962) Földtani jelentés a Ny-Mecseki (Gyúrúfü) kvarcporfír földtani, kőzettani és radiológiai vizsgálatának eredményeiről. Report, Mecsekérc Ltd. (former Mecsek Ore Mining Company)

Szederkényi T, Haas J, Nagymarosy A, Hámor G (2013) Geology and history of evolution of the Tisza Mega-unit. In: Haas J (ed) Geology of Hungary, pp 103-148

Szemerédi M, Varga A, Lukács R, Pál-Molnár E (2016) Petrography of the Gyúrúfú Rhyolite Formation, Western Mecsek Mts, Hungary. Földtani Közlöny 146(4):335-354 (in Hungarian with English abstract)

Szemerédi M, Varga A, Lukács R, Pál-Molnár E (2017) Petrography of the Gyürúfú Rhyolite Formation, northern foreland of the Villány Mts, Hungary. Földtani Közlöny 147(4):357-382. https:// doi.org/10.23928/foldt.kozl.2017.147.4.357 (in Hungarian with English abstract)

Szemerédi M, Varga A, Szepesi J, Pál-Molnár E, Lukács R (in press) Lavas or ignimbrites? Permian felsic volcanic rocks of the Tisza Mega-unit revisited: a petrographic study (SE Hungary). Central European Geology

Szepesi J, Harangi SZ, Lukács R, Pál-Molnár E (2016) Facies analysis of a Late Miocene lava dome field in the Tokaj Mts. (CarpathianPannonian Region): implication of a silicic caledera structure?
In: Branca S, Groppelli G, Lucchi F, Sulpizio R (eds) Geological fieldwork in volcanic areas: mapping techniques and applications III. Workshop on Volcano Geology, July 3-10, 2016, Sicily. Abstract book, pp 60-63

Vermeesch P (2018) IsoplotR: a free and open toolbox for geochronology. Geosci Front 9:1479-1493. https://doi.org/10.1016/j. gsf.2018.04.001

Vincze J, Sólymos G, Ditrói Puskás Z, Kósa L (2011) Uranium-ore micro-veins in granite from the western part of the Mecsek Mts (Hungary). Földtani Közlöny 141(4):325-339 (in Hungarian with English abstract)

von Quadt A, Wotzlaw J-F, Buret Y, Large SJE, Peytcheva I, Trinquier A (2016) High-precision zircon U/Pb geochronology by ID-TIMS using new $1013 \mathrm{ohm}$ resistors. J Anal Atom Spectrom 31(3):658665. https://doi.org/10.1039/c5ja00457h

Vozár J (1997) Rift-related volcanism in the Permian of the Western Carpathians. In: Grecula P, Hovorka D, Putiš M (eds) Geological evolution of the Western Carpathians. Mineralia Slovaca-Monograph, Bratislava, pp 225-234

Vozárová A, Šmelko M, Paderin I (2009) Permian single crystal U-Pb age of the Rožňava Formation volcanites (Southern Gemeric Unit, Western Carpathians, Slovakia). Geol Carpath 60(6):439-448. https://doi.org/10.2478/v10096-009-0032-1

Vozárová A, Presnyakov S, Šarinová K, Šmelko M (2015) First evidence for Permian-Triassic boundary volcanism in the Northern Gemericum: geochemistry and U-Pb zircon geochronology. Geol Carpath 66:375-391. https://doi.org/10.1515/geoca-2015-0032

Vozárová A, Rodionov N, Vozár J, Lepekhina E, Šarinová K (2016) $\mathrm{U}-\mathrm{Pb}$ zircon ages from Permian volcanic rocks and tonalite of the Northern Veporicum (Western Carpathians). Geol Carpath 61:221-237. https://doi.org/10.3190/jgeosci.215

Wiedenbeck M, Allé P, Corfu F, Griffin WL, Meier M, Oberli F, von Quadt A, Roddick JC, Spiegel W (1995) Three natural zircon standards for $\mathrm{U}-\mathrm{Th}-\mathrm{Pb}, \mathrm{Lu}-\mathrm{Hf}$ trace element and REE analyses. Geostand Newsl 19:1-23. https://doi.org/10.1111/j.1751908x.1995.tb00147.x

Wilcock MAW, Cas RAF, Giordano G, Morelli C (2013) The eruption, pyroclastic flow behaviour, and caldera in-filling processes of the extremely large volume $\left(>1290 \mathrm{~km}^{3}\right)$, intra- to extra-caldera, Permian Ora (Ignimbrite) Formation, Southern Alps, Italy. J Volcanol Geotherm Res 265:102-126. https://doi.org/10.1016/j.jvolgeores .2013.08.012

Wilson M, Neumann ER, Davies GR, Timmerman MJ, Heermans M, Larsen BT (2004) Permo-carboniferous magmatism and rifting in Europe. Geological Society Special Publication No. 223, London

Winchester JA, Floyd PA (1977) Geochemical discrimination of different magma series and their differentiation products using immobilile elements. Chem Geol 20:325-343. https://doi. org/10.1016/0009-2541(77)90057-2

\section{Affiliations}

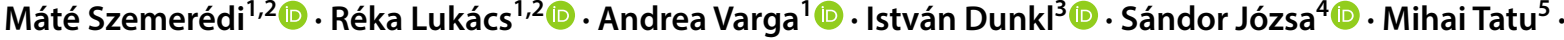

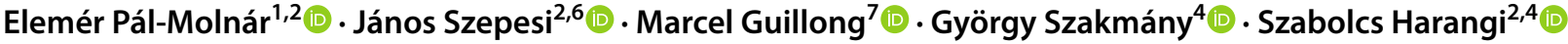

\author{
Réka Lukács \\ reka.harangi@gmail.com \\ Andrea Varga \\ raucsikvarga@geo.u-szeged.hu \\ István Dunkl \\ istvan.dunk1@geo.uni-goettingen.de
}

\author{
Sándor Józsa \\ sandor.jozsa@geology.elte.hu \\ Mihai Tatu \\ mtatu@geodin.ro \\ Elemér Pál-Molnár \\ palm@geo.u-szeged.hu
}


János Szepesi

szepeja@gmail.com

Marcel Guillong

marcel.guillong@erdw.ethz.ch

György Szakmány

gyorgy.szakmany@geology.elte.hu

Szabolcs Harangi

szabolcsharangi@gmail.com

1 Department of Mineralogy, Geochemistry and Petrology, 'Vulcano' Petrology and Geochemistry Research Group, University of Szeged, Egyetem st. 2, Szeged 6722, Hungary

2 MTA-ELTE Volcanology Research Group, Pázmány Péter sétány 1/C, Budapest 1117, Hungary
3 Geoscience Center, Department of Sedimentology and Environmental Geology, University of Göttingen, Goldschmidtstr. 3, 37077 Göttingen, Germany

4 Department of Petrology and Geochemistry, Eötvös Loránd University, Pázmány Péter sétány 1/C, Budapest 1117, Hungary

5 Institute of Geodynamics, Romanian Academy, 19-21, Jean-Luis Calderon St., Bucharest-37, Romania

6 Isotope Climatology and Environmental Research Centre (ICER), Institute of Nuclear Research, Hungarian Academy of Sciences, Bem tér 18/C, Debrecen 4026, Hungary

7 Department of Earth Sciences, Institute of Geochemistry and Petrology, ETH Zürich, Clausius strasse 25, 8092 Zurich, Switzerland 